\title{
Noncoding RNA:RNA Regulatory Networks in Cancer
}

\author{
Jia Jia Chan ${ }^{1}$ and Yvonne Tay ${ }^{1,2, *}$ \\ 1 Cancer Science Institute of Singapore, Centre for Translational Medicine, National University of Singapore, \\ Singapore 117599, Singapore; jia.chan@nus.edu.sg \\ 2 Department of Biochemistry, Yong Loo Lin School of Medicine, National University of Singapore, \\ Singapore 117597, Singapore \\ * Correspondence: yvonnetay@nus.edu.sg; Tel.: +65-6516-7756; Fax: +65-6873-9664
}

Received: 3 April 2018; Accepted: 25 April 2018; Published: 27 April 2018

\begin{abstract}
Noncoding RNAs (ncRNAs) constitute the majority of the human transcribed genome. This largest class of RNA transcripts plays diverse roles in a multitude of cellular processes, and has been implicated in many pathological conditions, especially cancer. The different subclasses of ncRNAs include microRNAs, a class of short ncRNAs; and a variety of long ncRNAs (lncRNAs), such as lincRNAs, antisense RNAs, pseudogenes, and circular RNAs. Many studies have demonstrated the involvement of these ncRNAs in competitive regulatory interactions, known as competing endogenous RNA (ceRNA) networks, whereby lncRNAs can act as microRNA decoys to modulate gene expression. These interactions are often interconnected, thus aberrant expression of any network component could derail the complex regulatory circuitry, culminating in cancer development and progression. Recent integrative analyses have provided evidence that new computational platforms and experimental approaches can be harnessed together to distinguish key ceRNA interactions in specific cancers, which could facilitate the identification of robust biomarkers and therapeutic targets, and hence, more effective cancer therapies and better patient outcome and survival.
\end{abstract}

Keywords: cancer; miRNA; lncRNA; circRNA; pseudogene; ceRNA

\section{Introduction}

Recent advances in high-throughput sequencing technologies and computational platforms have been pivotal towards the discovery and classification of a class of RNA species, collectively known as the noncoding RNAs (ncRNAs). These ncRNAs are the result of pervasive transcription of the mammalian genome and constitute the majority of the transcribed genome, of which only $1-2 \%$ code for proteins [1,2]. As such, tremendous interest in this field has seen numerous studies dissecting and delineating the coding-independent functions of this novel class of RNAs. Various ncRNAs have been shown to play key roles in important biological processes and their deregulation has been implicated in different diseases, including cancer [3-8].

Noncoding RNAs comprise a diverse range of RNA species, including rRNAs and others that can be further categorized into short ncRNAs and long ncRNAs (lncRNAs) (Figure 1). Short ncRNAs consist of microRNAs (miRNAs), siRNAs, snoRNAs, rRNAs, tRNAs, and Piwi-interacting RNAs (piRNAs). The first miRNA, lin-4, was identified in Caenorhabditis elegans and has since sparked an avalanche of miRNA research leading to the characterization of its biogenesis, regulatory functions, and involvement in human diseases [9,10]. miRNAs are small ncRNAs around 22 nucleotides long and execute their post-transcriptional regulatory effects by binding to specific sites known as miRNA response elements (MREs) on their target transcripts, resulting in either transcript degradation or translational inhibition [11,12]. Various studies have demonstrated tissue- and cell-type specific 
expression of miRNAs, which could exhibit either tumor suppressive or oncogenic effects in a context-dependent manner $[13,14]$.

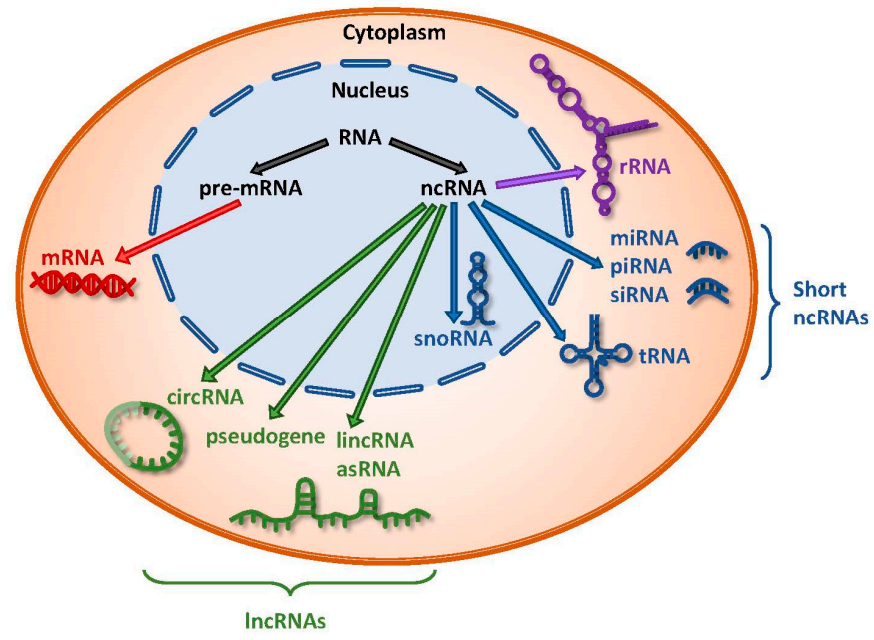

Figure 1. Coding and noncoding classes of RNA. Precursor messenger RNA (pre-mRNA) gives rise to protein-coding messenger RNA (mRNA). Noncoding RNAs (ncRNAs) include ribosomal RNA (rRNA) and other species that can be categorized into short and long ncRNAs. Short ncRNAs consist of microRNA (miRNA), Piwi-interacting RNA (piRNA), small interfering RNA (siRNA), transfer RNA (tRNA), and small nucleolar RNA (snoRNA). Long ncRNAs (lncRNAs) include long intergenic ncRNA (lincRNA), antisense RNA (asRNA), pseudogenes, and circular RNA (circRNA).

LncRNAs are defined as transcripts greater than 200 nucleotides, transcribed by RNA polymerase II, but not translated into proteins [15]. They can also be subjected to common post-transcriptional modifications, including 5'-capping, 3'-polyadenylation, and splicing [15]. Furthermore, recent transcriptome profiling studies have demonstrated that lncRNAs exhibit highly specific lineage, spatio-temporal, and tissue- and cell-type expression patterns [2,16,17]. LncRNAs constitute the largest class of ncRNAs in the mammalian genome, and they can be further classified into subclasses based on their different properties, the most common of which are long intergenic ncRNAs (lincRNAs), antisense RNAs (asRNAs), pseudogenes, and circular RNAs (circRNAs) (Figure 1).

The prominent classes of lncRNAs share a common functionality in their ability to shape gene expression by titrating miRNAs in a phenomenon known as the competing endogenous RNA (ceRNA) hypothesis $[18,19]$. Some lncRNAs also encode miRNAs that contribute to oncogenesis. Deregulation in their expression has been implicated in various diseases, including cancer [6,20-22]. Studies have demonstrated conservation of different ncRNA classes amongst various vertebrates. In particular, miRNA sequences and promoters are highly conserved between human and mouse [23]. Evolutionary conservation of lncRNAs is less clear due to the limitations of currently available alignment tools [24]. However, several lncRNA orthologs have been shown to contain highly conserved secondary structures and functions [24]. This conservation of ncRNAs across species carries the implication that ceRNA activities are not limited to humans, which could have a profound effect on translational research.

In this review, we first provide an overview of ceRNA interactions and the underlying molecular mechanisms, followed by a discussion on the roles of different lncRNA classes as ceRNAs and modulators of gene expression in cancer, their cellular localization, and the implications in ceRNA regulation, and finally, the diagnostic and prognostic value of ceRNA networks.

\section{Competing Endogenous RNA (ceRNA) Networks and Regulation}

Earlier miRNA studies focused only on the unidirectional regulation of target transcripts. However, with an increasing understanding on the mechanisms involved in miRNA targeting, 
the concept of reciprocal regulation began to evolve. Since each miRNA is able to target hundreds or thousands of genes, and similarly, multiple miRNAs can simultaneously target a single RNA transcript with many MREs, transcripts containing MREs for the same miRNA can coregulate one another (Figure 2A) [18].

A

CERNA A

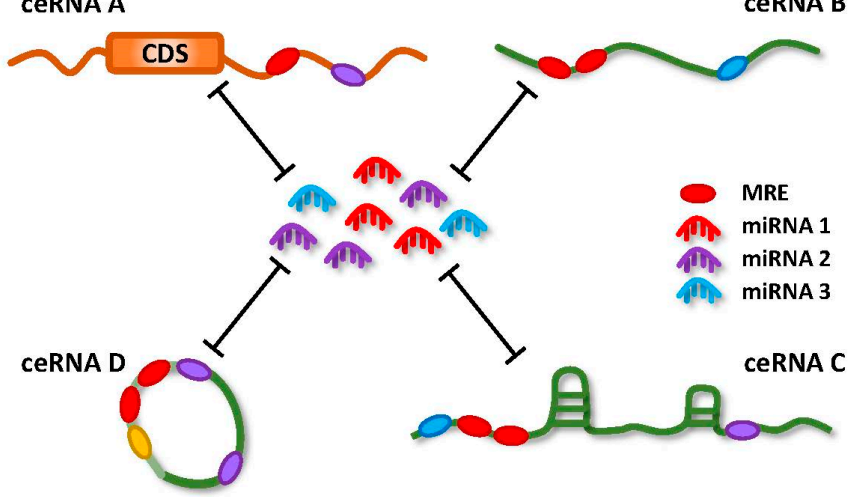

B

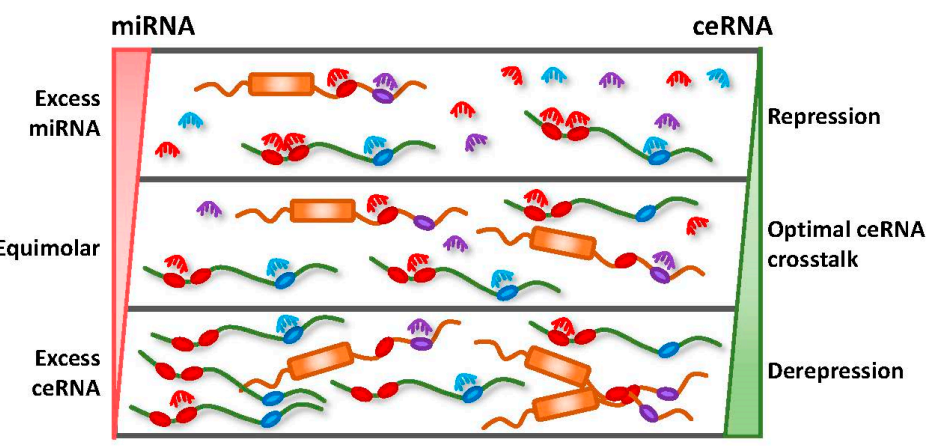

Figure 2. Competing endogenous RNA (ceRNA) networks of mRNA/miRNA/lncRNA. (A) miRNAs bind to specific miRNA response elements (MREs), which are found on coding (ceRNA A) and noncoding transcripts (ceRNA B, C and D) to suppress gene expression. Transcripts with MREs for the same miRNAs can compete for binding to a shared pool of miRNAs to reduce their availability (ceRNA A-D can compete for miRNA 1; ceRNA A, C, and D compete for miRNA 2; ceRNA B and C compete for miRNA 3). Transcripts with more MREs (for different miRNAs and of mixed affinities) may cooperatively bind miRNAs for more effective competition. MREs are represented by ovals that are in corresponding colors to their targeting miRNAs. (B) Schematic illustrating the conditions for optimal ceRNA crosstalk. Excess miRNAs compared to their targets leads to target repression, whereas, excess ceRNA molecules and low miRNA concentrations result in depression of target expression. Optimal ceRNA crosstalk occurs when miRNAs and their targets are in equimolar concentrations.

Competitive miRNA binding was first observed using artificial miRNA sponges which were shown to derepress their respective miRNA targets, and act as effective inhibitors for multiple miRNAs both in vitro and in vivo [25-28]. Following this, the first endogenous miRNA sponge was described in plants, whereby the ncRNA IPS1 (Induced by Phosphate Starvation 1) from Arabidopsis thaliana sequestered miR-399 and inhibited its activity through "target mimicry" [29]. Although most miRNA targets in plants are cleaved due to their almost perfect miRNA complementarity, the miR-399 motif on IPS1 contains a mismatched loop at the miRNA cleavage site that abolishes cleavage. Thus, IPS1 could act as an effective miR-399 sponge and alter the stability of the miR-399 target, $\mathrm{PHO} 2$ (phosphate 2) mRNA. Despite this, protein-coding mRNAs with miRNA binding sites were initially thought to act as "pseudotargets" that compete for miRNA binding, but are less sensitive to expression repression [30]. However, they were later shown to be authentic miRNA targets in several landmark studies in the field. 
Poliseno et al. demonstrated coregulation of pseudogenes PTENP1 (phosphatase and tensin homolog pseudogene 1) and KRASP1 (KRAS proto-oncogene, GTPase pseudogene 1) with their cognate genes, the tumor suppressor PTEN (phosphatase and tensin homolog), and oncogenic KRAS (KRAS proto-oncogene, GTPase), respectively [31]. This was mediated by competitive binding for their shared miRNAs, consequently affecting tumor growth and development. Several studies further delineated the reciprocal regulatory network between PTEN and other protein-coding genes in vitro and in vivo [32-34]. Karreth et al. also reported ceRNA-mediated regulation between proto-oncogene BRAF (B-Raf proto-oncogene, serine/threonine kinase) and its pseudogene BRAFP1 (B-Raf pseudogene 1), and their murine counterparts Braf and Braf-rs1, to induce malignancy in mice, further reinforcing the functionality of pseudogenes [35]. Other than mRNAs and transcribed pseudogenes, recent studies have shown that lncRNAs and circRNAs also carry MREs and participate in ceRNA regulation [19,22]. These observations add another dimension to the already complicated posttranscriptional landscape and highlight the importance of coding-independent functions of a large proportion of the transcriptome.

These seminal findings were accompanied by various studies that have provided important insights into the molecular mechanisms that dictate effective ceRNA crosstalk, a topic of much debate $[12,36]$. There has been repeated emphasis on the importance of stoichiometry, with optimal ceRNA crosstalk occurring at near-equimolar ratio of all participating members within a network (Figure 2B) [37-39]. The relative abundance of ceRNAs and miRNAs, the number of MREs shared between ceRNAs, and the total number of MREs for specific miRNAs are also critical for driving ceRNA crosstalk [37]. Although some have debated against ceRNA regulation for highly expressed miRNAs, as they require non-physiological levels of MREs to facilitate target derepression [37-39], Denzler et al. later showed that additional factors could influence miRNA competition under such conditions [40]. In their "mixed affinity model", target derepression is possible, due to cooperative binding of the same or different miRNA families when multiple MREs of different binding affinities are closely spaced (Figure 2A).

Powers et al. quantitatively illustrated the effective sponging of an endogenous and abundantly expressed miRNA, let-7, using the neuroblastoma cancer model [41]. Even in the absence of LIN28B (lin-28 homolog), a known let-7 antagonist, the amplified expression of $M Y C N$ (MYCN proto-oncogene, bHLH transcription factor) alone was sufficient to sponge let-7, which was present at a substantial range of 2000-7000 copies per cell. Another study also outlined the sequestration of an abundant miRNA, miR-16, by TYRP1 (tyrosinase-related protein 1) mRNA in melanoma [42]. Although there were more copies of miR-16 per cell, each TYRP1 transcript carried three non-canonical miR-16 MREs, thus, the presence of TYRP1 alone could achieve effective target abundance to potentially sponge the entire pool of miR-16 per cell. Furthermore, due to the non-canonical nature of the MREs, Gilot et al. showed that miR-16 binding to TYRP1 does not induce decay, and instead, increases TYRP1 transcript expression, making TYRP1 a robust miR-16 decoy with oncogenic capacity in melanoma [42]. These studies demonstrated that, when all criteria are met, it is physiologically possible to sponge even highly abundant miRNAs.

\section{The Links between Long Noncoding RNAs and microRNAs}

Although a few lncRNAs, such as H19 and XIST (X-Inactive Transcript), were identified, and their coding-independent functions characterized in the early 1990s [43-48], the existence and biological relevance of the vast majority of lncRNAs were only gradually being recognized a decade later. Several lncRNAs, such as XIST, H19, HOTAIR (Hox Transcript Antisense RNA), MALAT1 (Metastasis Associated Lung Adenocarcinoma Transcript 1), and NEAT1 (Nuclear Enriched Abundant Transcript 1), are well studied and known to play key regulatory roles in diverse processes, such as $\mathrm{X}$ inactivation, imprinting, development, epigenetic modifications, mRNA processing, and the organization of nuclear architecture [7,49]. Recently, their role as miRNA decoys in ceRNA regulation is also gaining prominence. 


\subsection{Cytoplasmic IncRNAs}

\subsubsection{H19}

H19 is a maternally expressed and paternally imprinted gene that codes for a $2.7 \mathrm{~kb}$ lncRNA [43,50]. It is abundantly expressed during development and postnatal growth, but globally repressed during adulthood. Tumor suppressor p53 is also known to epigenetically suppress H19 expression [51]. Despite this, elevated H19 expression is found in many cancer types, and appears to play a role in genome instability [52]. The oncogenic functions of $H 19$ were initially thought to be mediated by miR-675, a miRNA derived from H19, which targets and suppresses a myriad of transcripts through either direct or indirect targeting [53]. However, there is now increasing evidence pointing towards the additional role of $H 19$ as a miRNA decoy in tumorigenesis. H19 is a prominent player in epithelial-to-mesenchymal (EMT) regulation, in part through its ceRNA activities that modulate the following miRNA(s)/gene(s) axes: miR-29b-3p/DNMT3B (DNA methyltransferase 3 beta), miR-200b/miR-200c/let-7b/GIT2/CYTH3 (GIT ArfGAP 2/cytohesin 3), let-7/HMGA2 (high mobility group AT-hook 2), miR-138/miR-200a/VIM/ZEB1/ZEB2 (vimentin/zinc finger E-box binding homeobox 1/2), and miR-484/ROCK2 (Rho associated coiled-coil containing protein kinase 2) [54-59]. A number of studies have also highlighted its binding preference to let-7 miRNAs, whilst $H 19$ could also form a reciprocal negative feedback loop with the established let-7 target, as well as antagonist, LIN28 for breast cancer stem cell maintenance $[60,61]$.

\subsubsection{Growth Arrest-Specific 5 (GAS5)}

GAS5 is $\sim 630 \mathrm{nt}$ long transcript that has been linked to the regulation of apoptosis, proliferation, metastasis, angiogenesis, and DNA repair; and is widely reported to be downregulated in various cancers [62,63]. Multiple ceRNA studies of GAS5 have highlighted its tumor suppressive roles, in particular, through its regulation of the PTEN tumor suppressor gene. Through its interaction with miR-21 and miR-222, GAS5 upregulates PTEN to activate the PTEN/AKT (AKT serine/threonine kinase 1/protein kinase B) pathway, and suppresses growth in thyroid, gastric, endometrial, cervical, and lung cancers [63-67]. Furthermore, the GAS5/miR-21/PTEN axis influences cisplatin resistance and chemosensitivity, in cervical cancer and non-small cell lung cancer (NSCLC), respectively [66,67]. The only study demonstrating oncogenic properties of GAS5 showed that it upregulated CXCR4 (C-X-C motif chemokine receptor 4) by competing for miR-301a, in turn activating Wnt/ $\beta$-catenin and NF- $\mathrm{kB}$ (nuclear factor kappa B) signaling to promote proliferation, migration, and invasion in esophageal cancer [68], suggesting that GAS5 could exert opposing functions in a tissue-specific manner.

\subsubsection{LincRNA, Regulator of Reprogramming (Linc-ROR)}

Linc-ROR was first identified as a lncRNA that regulates the reprogramming of pluripotent stem cells, which could partly be due to its miRNA sponging effect that regulates stem cell factors OCT4 (POU class 5 homeobox 1), NANOG (Nanog homeobox) and SOX2 (SRY-box 2) [69,70]. Interestingly, in the context of human cancers, it has also been associated with stem cell maintenance in various cancer. Linc-ROR was reported to sponge many members of the let-7 miRNA family, as well as miR-93-5p, miR-145-3p, miR-320a, and miR-320b, to maintain stem cell properties of pancreatic cancer cells and promote tumorigenesis [71]. Furthermore, linc-ROR potentiates the stem cell phenotype and tumorigenesis of esophageal cancer by derepressing SOX9 via multiple miRNAs [72].

\subsubsection{Noncoding RNA Activated by DNA Damage (NORAD)}

NORAD is a conserved $5.3 \mathrm{~kb}$ lncRNA which is broadly and abundantly expressed in human tissues and cell lines [73]. Lee et al. showed that NORAD functioned as a molecular decoy to sequester PUMILIO (pumilio RNA binding family member) proteins, regulate mitosis, and maintain genomic stability. As NORAD is relatively new in the field, only one study has shown its ceRNA potential 
through its competition for miR-125a-3p with RHOA (ras homolog family member A), to promote EMT and metastasis in pancreatic cancer [74].

\subsection{Nuclear LncRNAs}

Although miRNAs have been known to primarily localize to and exert their effects in the cytoplasm, recent studies have identified various classical nuclear lncRNAs that could function as miRNA sponges. This could, in part, be due to different signals and mechanisms that drive the translocation of miRNAs and lncRNAs between cellular compartments (see Section 4).

\subsubsection{X-Inactive Transcript (XIST)}

$\mathrm{XIST}$ is a $17 \mathrm{~kb}$ lncRNA located on the $\mathrm{X}$ chromosome and is well known for its role as a major effector of $X$ inactivation [75]. More recent work revealed that XIST could also function as a ceRNA, by sponging different miRNAs from various protein-coding genes. XIST was shown to exhibit tumor suppressive properties in hepatocellular carcinoma (HCC) by acting as a miRNA decoy for tumor suppressor genes, SMAD7 (SMAD family member 7) and PTEN, by sponging miR-92b and miR-181a, respectively, and suppressing cell proliferation, metastasis, and invasion [76,77]. Conversely, Mo et al. found that XIST regulates the miR-139-5p/PDK1 (pyruvate dehydrogenase kinase 1) axis to promote cell cycle progression and inhibit apoptosis in HCC [78]. Several other studies demonstrated oncogenic effects of XIST through different miRNA/gene axes, such as miR-101/EZH2 (enhancer of zeste 2 polycomb repressive complex 2 subunit) in gastric cancer, miR-124/ AR (androgen receptor) in bladder cancer, and miR-133a/EGFR (epidermal growth factor receptor) in pancreatic cancer, to commonly affect growth, invasion and migration [79-81]. Interestingly, as XIST is known to recruit polycomb repressive complex 2 (PRC2), of which $E Z H 2$ is a component, to facilitate $\mathrm{X}$ inactivation; competitive interactions between XIST and EZH2 could potentially add another layer of regulation to this process [82].

\subsubsection{Nuclear Enriched Abundant Transcript 1 (NEAT1)}

NEAT1 is a $3.2 \mathrm{~kb}$ transcript which localizes primarily to nuclear paraspeckles and plays an important structural role in paraspeckle formation and maintenance [83,84]. NEAT1 is often upregulated in cancer and exhibits an oncogenic role by sponging tumor suppressive miRNAs, in turn, upregulating oncogene expression. Studies have identified several common genes and miRNAs that are ceRNA partners of NEAT1 different cancer types, for example, the NEAT1/miR-107/CDK6 (cyclin dependent kinase 6) axis is deregulated in laryngeal squamous cell carcinoma (LSCC) and glioma $[85,86]$. Other than affecting regular cellular processes, such as apoptosis and cell cycle, this axis also regulates stem cell-like properties in glioma. Additionally, NEAT1 modulates the expression of well-known oncogenes, such as STAT3 (signal transducer and activator of transcription 3) and NRAS (NRAS proto-oncogene, GTPase), by competing for miR-506 and let-7e in gastric cancer and glioma, respectively, with a consequent increase in growth, invasion and migration [87,88]. Interestingly, a few studies have implicated different NEAT1 ceRNA axes in radioresistance, including miR-204/ZEB1 and miR-193b-3p/CCND1 (cyclin D1) [89,90].

\subsubsection{Metastasis Associated Lung Adenocarcinoma Transcript 1 (MALAT1)}

MALAT1 is a highly conserved lncRNA that is abundantly expressed in the nucleus. As its name suggests, MALAT1 has been associated with various pathological processes, particularly cancer, in which it regulates the expression of metastasis-associated genes [91-93]. Reports on MALAT1 have largely highlighted its oncogenic roles in various cancers. This is consistent with ceRNA studies on MALAT1 that demonstrated its regulation of various miRNA/oncogene axes to induce migration, invasion and cell proliferation in colorectal carcinoma (CRC), breast cancer, gallbladder cancer, NSCLC and oral squamous cell carcinoma (OSCC) [94-98]. MALAT1-mediated upregulation of STAT3 also correlates with its reported role in enhancing the expression of MRP1 (ATP binding cassette subfamily 
C member 1) and MDR1 (ATP binding cassette subfamily B member 1) through STAT3 activation, in turn driving cisplatin-resistance in lung cancer [99].

On the contrary, a recent study showed that MALAT1 is downregulated in CRC and various subtypes of breast cancer [100]. Kwok et al. also demonstrated that the reciprocal regulation of PTEN and MALAT1 transcript expression through their shared miRNAs (miR-17, miR-20a and miR-106b) suppressed migration and invasion [100].

\subsubsection{Plasmacytoma Variant Translocation 1 (PVT1)}

PVT1 is a well-known oncogenic lncRNA which is often co-amplified with the proto-oncogene $M Y C$ (MYC proto-oncogene, bHLH transcription factor) and is required for elevated MYC expression in cancer [101]. Through miR-186-5p, PVT1 modulated the expression of YAP1 (Yes associated protein 1) and HIF-1 $\alpha$ (hypoxia-inducible factor 1-alpha) to effect invasion and migration in HCC and gastric cancer; ATG7 (autophagy related 7) and BECN1 (beclin 1) to induce protective autophagy and angiogenesis in glioma; and TWIST1 to promote EMT in prostate cancer [102-105]. Additionally, PVT1 regulates HIF-1 $\alpha$ through miR-199a-5p during hypoxia in NSCLC, and thus, could be a potential hypoxia therapeutic target [106]. A study has also highlighted the ability of PVT1 to simultaneously regulate multiple genes [BCL2 (B-cell lymphoma 2, apoptosis regulator), CCND1, FASN (fatty acid synthase)] through a single miRNA, miR-195, to inhibit apoptosis and cell cycle arrest while enhancing invasion in osteosarcoma [107]. Furthermore, different splice variants of PVT1 have been reported to bind preferentially to the miR-200 family. These splice variants either compete with PVT1 for miRNA binding or affect its ceRNA activity, due to their differential expression levels between normal and cancer states $[108,109]$. Consistent with its antagonistic role towards miR-200, Zhang et al. showed that PVT1 also epigenetically silences miR-200b by recruiting EZH2 to the miR-200b promoter to increase the repressive H3K27me3 mark, resulting in cervical cancer growth and progression [110]. Intriguingly, the PVT1 locus also encodes multiple miRNAs, such as miR-1204, miR-1205, miR-1206, miR-1207-5p, miR-1207-3p, miR-1208, a few of which have demonstrated oncogenic capacity [111,112]. Thus, PVT1 is able to drive tumorigenic effects not only through antagonizing tumor suppressive miRNAs, but also by contributing to the physiological pool of oncogenic miRNAs.

\subsection{Antisense RNAs}

\subsubsection{Hox Transcript Antisense RNA (HOTAIR)}

HOTAIR is a $2.2 \mathrm{~kb}$ lncRNA involved in epigenetic and chromatin regulation via its interaction with PRC2 [113,114]. Consistent with this function, HOTAIR also epigenetically silences the expression of miRNAs that it sponges. In gastric cancer, it sequesters miR-34a to upregulate c-Met (MET proto-oncogene, receptor tyrosine kinase) and SNAIL (snail family transcriptional repressor 1) to promote EMT and metastasis; at the same time, it interacts with EZH2 or recruits PRC2 to the promoter of miR-34a to repress its expression [115,116]. In bladder cancer, the HOTAIR/miR-205/CCNJ (cyclin J) axis has been shown to promote growth, whilst HOTAIR silences the tumor suppressive miR-205 by disrupting the balance of histone modifications on the miRNA promoter [117]. In a similar fashion, HOTAIR epigenetically silences miR-663b to upregulate its target IGF2 (insulin like growth factor 2) and promote pancreatic cancer growth [118]. Collectively, these data suggest that HOTAIR could inhibit tumor suppressive miRNAs through a combination of multiple mechanisms to amplify its oncogenic effects.

\subsubsection{HOXD Antisense Growth-Associated lncRNA (HOXD-AS1)}

HOXD-AS1 is known to play various roles in different cancer types in which it can exhibit tissue-dependent tumor suppressive or oncogenic effects. To date, only three studies have demonstrated its ability to act as a miRNA decoy to promote cancer progression. HOXD-AS1 modulates the miR-130a/E2F8 (E2F transcription factor 8) axis in glioma, the miR-130a-3p/SOX4 
(SRY-box 4) axis in liver cancer, and the miR-608/FZD4 (frizzled class receptor 4) axis in ovarian cancer [119-121]. Through its regulation of SOX4, HOTAIR also indirectly activated EZH2 and MMP2 (matrix metallopeptidase 2) to facilitate HCC metastasis [120].

\subsection{Pseudogenes}

Pseudogenes originate from gene duplication and through evolution, have acquired various mutations; thus, they were once considered "junk DNA", due to the loss of their protein-coding capacity and supposed functionality [122]. However, this theory has since been dispelled by transcriptomic and proteomics analyses validating the presence of pseudogene-derived transcripts and proteins $[2,123]$. Furthermore, the last decade has seen the functional characterization of various pseudogenes as regulators of gene expression, mainly by acting as miRNA decoys $[18,19]$.

\subsubsection{Tumor Suppressive Pseudogenes}

The PTEN pseudogene, PTENP1, was the first pseudogene shown to regulate the expression of its parental gene by binding and sequestering PTEN-targeting miR-17, miR-19, miR-20a, and miR-21 [31]. Several later studies have reinforced these findings by demonstrating the functional PTENP1/miR-21/PTEN axis in clear cell renal carcinoma and oral squamous carcinoma $[124,125]$. The tumor suppressive effects of the PTENP1/miR-106b/miR-93/PTEN ceRNA network have also been demonstrated in gastric cancer [126]. Finally, Gong et al. showed that PTENP1 can also exert its ceRNA effects on genes other than PTEN in the miR-17-5p/SOCS6 (suppressor of cytokine signaling 6) axis to inhibit the growth of esophageal squamous cell carcinoma [127].

Other tumor suppressive pseudogenes have also been identified as miRNA sponges that modulate their parental gene expression and tumorigenesis. TUSC2P (tumor suppressor 2, mitochondrial calcium regulator pseudogene) regulated TUSC2 (tumor suppressor 2, mitochondrial calcium regulator), as well as TIMP2 and TIMP3 (tissue inhibitor of metalloproteinases 2 and 3) by sequestering multiple miRNAs, including miR-17, miR-93, miR-299-3p, miR-520a, miR-608 and miR-661, to reduce the growth and migratory capacity of various cancer cell lines [128]. INTS6P1 (integrator complex subunit 6 pseudogene) and INTS6 (integrator complex subunit 6) functioned as ceRNAs through miR-17-5p, whilst CTNNAP1 (catenin alpha 1 pseudogene) and CTNNA1 (catenin alpha 1) competed for miR-141, leading to cancer regression in HCC and CRC, respectively $[129,130]$. A study has also shown that the transcription factor FOXO3 (forkhead box O3) can be regulated in concert by its pseudogene FOXO3P (forkhead box $\mathrm{O} 3$ pseudogene) and circRNA circ-FOXO3 to inhibit growth and angiogenesis in breast cancer [131]. These effects are facilitated by competitive binding of FOXO3P/circ-FOXO3/FOXO3 for eight miRNAs, some of which through multiple binding sites.

A study recently identified a tumor suppressive miRNA/gene/pseudogene network in prostate cancer through an unbiased screen. The network comprises multiple pseudogenes and miRNAs, and possesses tumor suppressive properties [132]. Chan et al. demonstrated reciprocal regulation between FTH1 (ferritin heavy chain 1) and its pseudogenes, which were required to modulate FTH1 expression and maintain physiological iron balance, possibly through cooperative miRNA sponging [132]. Perturbation of the network through a single miRNA or pseudogene disrupted iron homeostasis and enhanced prostate cancer growth, highlighting the delicate balance that governs a multicomponent ceRNA network.

\subsubsection{Oncogenic Pseudogenes}

Pseudogenes of two prominent proto-oncogenes, KRASP1 and BRAFP1, are validated ceRNA partners of their parental gene, KRAS and $B R A F$, respectively [31,35]. The ceRNA properties and oncogenic capacity of $B R A F P 1$ were characterized in detail, whereby its competitive binding to multiple miRNAs upregulated $B R A F$ expression to activate the MAPK (mitogen activated kinase-like protein) pathway and induce lymphoma in vivo [35]. 
Transcription factor OCT4 (or POU5F1) has multiple pseudogenes, OCT4-pg1, OCT4-pg3, OCT4-pg4, and OCT4-pg5, all of which contain well conserved miR-145 binding sites [31]. CeRNA activity between OCT4 pseudogenes and OCT4 were later confirmed by two independent studies that showed OCT4-pg4 and OCT4-pg5 competing for miR-145 to regulate OCT4 expression in HCC and endometrial carcinoma $[133,134]$.

RSU1P2, a pseudogene of Ras suppressor protein 1, is upregulated in cervical cancer and promotes tumorigenic phenotypes by sponging let-7a from IGF1R (insulin like growth factor 1 receptor), MYCN, and EPHA4 (EPH receptor A4) [135]. Furthermore, the transcription factor N-MYC was shown to activate RSU1P2 expression in a positive feedback loop to enhance its oncogenic capacity.

CYP4Z2P pseudogene derived from CYP4Z1 (cytochrome P450 family 4 subfamily Z member 1) has been implicated in breast cancer progression by sponging miR-125a, miR-197, miR-204, miR-211, and miR-1226 from CYP4Z1, resulting in enhanced tumor angiogenesis, tamoxifen resistance, and reduced apoptosis [136-138]. In these studies, CYP4Z2P and CYP4Z1 were also found to act as ceRNAs for CDK3 (cyclin dependent kinase 3) and hTERT (human telomerase reverse transcriptase) through miR-125a in sub-ceRNA networks that further potentiate cancer development.

Two HMGA1 (high mobility group AT-hook 1) pseudogenes, HMGA1P6 and HMGA1P7, were recently identified and shown to play critical roles in cancer progression as miRNA decoys for other genes [139]. Interestingly, by sponging multiple miRNAs, HMGA1P7 could also sustain the expression of $H 19$ and IGF2, two closely linked imprinting genes also implicated in adult malignancies. The same group later showed that HMGA1P7 could induce the expression of known oncogenic miR-483 and miR-675 through its ceRNA-mediated regulation of EGR1 (early growth response 1), a transcriptional factor that positively regulates these miRNAs [140]. Thus, ceRNA regulation of HMGA1P7 could contribute to malignant phenotypes through both direct and indirect mechanisms. Additionally, pseudogenes can function as molecular decoys, not only for their cognate genes, but also for non-related genes to drive different phenotypes.

\subsection{Circular RNAs}

CircRNAs were first discovered over 30 years ago, but thought to be non-functional byproducts of aberrant splicing [141]. Recent high-throughput RNA sequencing of non-polyadenylated transcriptomes have identified tens of thousands of different mammalian circRNAs, highlighting their widespread expression [142-146]. CircRNAs are products of backsplicing events on precursor mRNAs with the distinctive feature of a $3^{\prime}, 5^{\prime}$-phosphodiester bond at the "backsplice junction" [147,148]. They are evolutionary conserved, highly stable and abundant compared to their linear counterparts, and often expressed in a tissue type- and developmental stage-specific manner, properties which correlate with their diverse roles in transcriptional regulation, pre-mRNA splicing and the modulation of gene expression [148].

\subsubsection{Cerebellar Degeneration-Related Protein 1 Antisense RNA (CDR1as)}

CDR1as was one of the first circRNAs to be functionally characterized when Hansen et al. showed that CDR1as could behave as a potent miRNA sponge in mouse, zebrafish and human [144,149]. CDR1as has over 70 binding sites for miR-7, giving rise to its alias, ciRS-7 (circRNA sponge for miR-7) [144,149]. As it is abundantly expressed in the brain, initial studies focused on its sponging activities to regulate brain function [144,150]. However, there is increasing evidence that the CDR1as/miR-7 axis also plays a role in cancer development. Collectively, CDR1as upregulates CCNE1 (cyclin E1) and PIK3CD (phosphatidylinositol-4,5-Bisphosphate 3-Kinase Catalytic Subunit Delta) in HCC, EGFR and IGF1R in CRC, RELA (RELA proto-oncogene, NF-kB subunit) in NSCLC, and activates the PI3K/AKT pathway in gastric cancer to promote cell proliferation, migration and invasion [151-154]. 


\subsubsection{Circ-ITCH (Itchy E3 Ubiquitin Protein Ligase)}

Circ-ITCH was identified through screening of RNA-seq reads for backsplice junctions [144]. It is derived from several exons of the E3 ubiquitin protein ligase, $\mathrm{ITCH}$, which is known for its tumor suppressive effects via its role in promoting ubiquitin-mediated degradation of DVL2 (dishevelled segment polarity protein 2) to inhibit canonical Wnt signaling [155]. Not surprisingly, circ-ITCH has been reported to antagonize miR-7, miR-17 and miR-214, to upregulate ITCH and impede lung and esophageal squamous cell carcinoma growth by blocking the Wnt/ $\beta$-catenin pathway $[156,157]$. Similarly, circ-ITCH sequestered miR-7 and miR-224 to upregulate $p 21$ and PTEN expression and inhibit bladder cancer progression [158].

\subsubsection{CircHIPK3 (Homeodomain Interacting Protein Kinase 3)}

CircRNA profiling was used to identify circHIPK3 as a highly abundant circRNA in various cancers [146]. CircHIPK3 is derived from exon-2 of HIPK3 and exhibits oncogenic capacity by sponging miR-124 to promote cancer cell proliferation. Although miR-7 has largely been reported as oncogenic, a recent study showed that circHIPK3 promoted CRC growth and metastasis by inhibiting miR-7 and upregulating its targeted proto-oncogenes FAK (focal adhesion kinase), IGF1R, EFGR and YY1 (Yin Yang 1 transcription factor) [159]

\subsubsection{CircPVT1}

PVT1 is a well-studied oncogenic IncRNA that also forms a circRNA, circPVT1, which was identified through a screen for senescence-associated, differentially expressed circRNAs [160]. The study highlighted the role of ceRNA regulation involving circPVT1, let-7 and its target genes, IGF2BP1 (insulin like growth factor 2 mRNA binding protein 1), KRAS and HMGA2, which were upregulated following let-7 inhibition. This resulted in enhanced cell proliferation and reduced senescence in various cancer types. Interestingly, circPVT1 expression can be transcriptionally enhanced by the mutant p53/YAP/TEAD complex, and functions as a decoy for miR-497-5p [161]. The subsequent increase in the expression of a range of cell proliferation genes promoted cell growth and migration in head and neck squamous cell carcinoma.

\subsubsection{Other Newly Identified circRNAs}

Other circRNAs have also been reported to exert their functions through their ceRNA activities. Expression profile screens of bladder carcinoma identified circ-MYLK (myosin light chain kinase) as a highly expressed circRNA which binds miR-29a and derepresses VEGFA (vascular endothelial growth factor A) to activate VEGFA/VEGFR2 (kinase insert domain receptor) signaling and promote growth, angiogenesis and metastasis [162]. Conversely, circMTO1 was identified as a downregulated circRNA in HCC, and it functions as a tumor suppressor by sponging miR-9 to upregulate $\mathrm{p} 21$ and suppress HCC development [163]. Another study focused on a novel circRNA, circCCDC66, on the basis that its parental genes have no known functions [164]. CircCCDC66 was shown to bind miR-33b and miR-93 to relieve their suppression of $M Y C$ and promote CRC progression.

\section{The Impact of Cellular Localization on miRNA-Mediated Gene Regulation}

The canonical miRNA function involves miRNA interaction with AGO2 (argonaute 2, RISC catalytic component) and other silencing factors to form the RNA-induced silencing complex (RISC) in the cytoplasm [165]. This is consistent with their role in ceRNA regulation involving pseudogenes and exonic circRNAs, which are predominantly found in the cytoplasm [142,143]. On the other hand, there has been much debate about the possibility of other lncRNAs acting as miRNA decoys, given their preference for nuclear localization $[2,166]$. Despite this, there is increasing evidence of miRNAs and lncRNAs shuttling between nuclear and cytosolic compartments. 
MALAT1 was reported to interact with RNA-binding protein HNRNPC (heterogeneous nuclear ribonucleoprotein $\mathrm{C}(\mathrm{C} 1 / \mathrm{C} 2))$ to translocate to the cytoplasm during the $\mathrm{G} 2 / \mathrm{M}$ phase to facilitate cell cycle progression [167]. An oncogenic lncRNA LNC00152 was recently shown to translocate to the cytoplasm upon hypoxic stress to act as a miRNA sponge for HIF1 and promote CRC progression [168]. Conversely, GAS5, which is more predominant in the cytoplasm, translocates to the nucleus during starvation to act as a molecular decoy that suppresses glucocorticoid-induced gene expression and sensitizes cells to apoptosis [169].

Nuclear import and functions of mature miRNAs also represent an emerging paradigm in transcriptional and post-transcriptional regulation. Several studies have identified and validated various components of the RISC complex, including AGO2, TNRC6 (trinucleotide repeat containing $6 \mathrm{~A})$ and the associated miRNAs, that are imported into the nucleus, as well as the mechanisms and mediators involved [170]. Similarly, miRNAs have also been shown to directly target or act in complex with AGO2 to recruit epigenetic factors to promoter regions to modify histone marks and gene expression [171,172].

Consistent with these findings, MALAT1, a primarily nuclear lncRNA, could be targeted by miR-9 in an AGO2-dependent manner in the nucleus [173]. Moreover, a recent study detected MALAT1targeting miR-17, miR-20a, miR-106b, and PTEN transcript (ceRNA partner of MALAT1) in nuclear fractions following cellular fractionation, and further observed their localization in the same cellular compartments using RNA-FISH in the CRC cell line HCT116 [100]. These observations suggest that similar mechanisms could be driving the miRNA competition by XIST, NEAT1, PVT1 and other nuclear lncRNAs. Therefore, it is possible for lncRNAs and miRNAs with different subcellular localization to participate in the same ceRNA networks upon specific physiological or extracellular cues.

\section{The Diagnostic and Prognostic Potential of ceRNA Interactions}

Most studies on IncRNAs and their competitive binding to miRNAs utilized differential expression profiling to identify potential candidates in different cancers. These lncRNAs and miRNAs are usually aberrantly expressed in specific cancers and are attractive therapeutic targets and biomarkers.

Indeed, several recent studies have started to exploit ceRNA interactions to identify differentially expressed mRNAs, miRNAs and lncRNAs with diagnostic and prognostic values. These studies utilized integrative analysis of datasets from The Cancer Genome Atlas (TCGA) database to systematically construct lncRNA/miRNA/mRNA ceRNA networks in various cancers [174-178]. The multifaceted approach includes differential expression profiling between normal and cancer samples, miRNA targeting predictions, survival and KEGG pathway analysis. Through this method, $\mathrm{Li}$ et al. identified and validated HOTAIR and UCA1 (urothelial cancer associated 1) as candidate biomarkers of gastric cancer that correlated with tumor size, TNM stage and lymphatic metastases [174]. Similarly, UCA1 was found to be a robust prognostic marker for diabetic pancreatic cancer, whilst both HOTAIR and UCA1 were involved in separate lncRNA/miRNA/lncRNA "competitive triples" that could stratify diabetic and non-diabetic pancreatic cancer patients with high accuracy [176]. Additionally, Wu et al. used mathematical models to build ceRNA interactions that can significantly divide patients into high- and low-risk groups in specific cancers [178].

Interestingly, a recent study also exploited ceRNA networks as a tool to predict drug responses across different cancers [179]. Analysis of sequence, expression and survival data of cancer patients treated with drugs were used to identify drug-response related ceRNAs (DRCEs). As a proof of concept, the authors found two NEAT1-related DRCEs in invasive breast cancer that may lead to poor response to tamoxifen therapy for patients with TP53 mutations. Given that several lncRNA-mediated ceRNA axes have been implicated in drug- and radioresistance, this predictive approach could be valuable for designing better therapies and improving patient outcome. 


\section{Closing Remarks}

In recent years, IncRNAs have emerged as a previously unappreciated class of gene expression modulators that regulate various cellular processes. Their role as competitive miRNA decoys gained momentum after various studies revealed that both endogenous and artificial miRNA sponges, as well as coding and noncoding transcripts, could act as effective miRNA regulators. Numerous studies have since identified many lncRNAs that can modulate gene expression through ceRNA regulation in various cancers (Table 1 ). 
Table 1. miRNA/ceRNA interactions in different cancers.

\begin{tabular}{|c|c|c|c|c|c|}
\hline Noncoding RNA Species & \multicolumn{2}{|c|}{ Competing Endogenous RNAs } & \multirow{2}{*}{$\begin{array}{c}\text { Shared miRNAs } \\
\text { miR-29b-3p }\end{array}$} & Cancer Type & References \\
\hline \multirow{35}{*}{ LncRNA } & & DNMT3B & & Bladder & [54] \\
\hline & & GIT2, CYTH3 & $\mathrm{miR}-200 \mathrm{~b}$, miR-200c, let-7b & Breast & [55] \\
\hline & & HMGA2 & let-7 & Pancreas, tongue & {$[56,57]$} \\
\hline & H19 & VIM, ZEB1, ZEB2 & miR-138, miR-200a & Colon & [58] \\
\hline & & ROCK2 & $\mathrm{miR}-484$ & Lung & [59] \\
\hline & & LIN28 & let-7 family & Breast & {$[60,61]$} \\
\hline & GAS5 & PTEN & miR-21, miR-222 & $\begin{array}{l}\text { Thyroid, gastric, endometrial, } \\
\text { cervical, lung }\end{array}$ & [63-67] \\
\hline & & CXCR4 & miR-301 & Esophageal & [68] \\
\hline & Linc-ROR & SOX9 & $\begin{array}{l}\text { let-7 family, miR-93, miR-145, miR-320a, miR-320b } \\
\text { miR-15b, miR-33a, miR-129, miR-145, and miR-206 }\end{array}$ & $\begin{array}{l}\text { Pancreas } \\
\text { Esophageal }\end{array}$ & $\begin{array}{l}{[71]} \\
{[72]}\end{array}$ \\
\hline & NORAD & RHOA & miR-125a-3p & Pancreas & [74] \\
\hline & & SMAD7 & miR-92b & Liver & [76] \\
\hline & & PTEN & miR-181a & Liver & [77] \\
\hline & & PDK1 & miR-139-5p & Liver & [78] \\
\hline & XIST & EZH2 & miR-101 & Gastric & [79] \\
\hline & & $A R$ & miR-124 & Bladder & [80] \\
\hline & & EGFR & miR-133a & Pancreas & [81] \\
\hline & & CDK6 & miR-107 & Laryngeal, glioma & {$[85,86]$} \\
\hline & & STAT3 & miR-506, let-7e & Gastric, glioma & {$[87,88]$} \\
\hline & NEAT1 & ZEB1 & miR-204 & Nasopharyngeal & [89] \\
\hline & & CCND1 & miR-193-3p & Cervical & [90] \\
\hline & & $H M G B 1$ & miR-129-5p & Colon & [94] \\
\hline & & & miR-1 & Breast & [95] \\
\hline & MALAT1 & $C D C 42$ & miR-206 & Gallbladder & [96] \\
\hline & & STAT3 & miR-124, miR-125b & Lung, oral & {$[97,98]$} \\
\hline & & PTEN & miR-17, miR-20a, miR-106b & Colon & [100] \\
\hline & & YAP1, HIF1- $\alpha$ & miR-186-5p & Liver, gastric & {$[102,103]$} \\
\hline & & $A T G 7, B E C N 1$ & miR-186 & Glioma & [104] \\
\hline & & TWIST1 & miR-186 & Prostate & [105] \\
\hline & $P V 11$ & HIF1- $\alpha$ & miR-199a-5p & Lung & [106] \\
\hline & & BCL2, CCND1, FASN & $\begin{array}{c}\text { miR-195 } \\
\text { miR-200 family }\end{array}$ & $\begin{array}{l}\text { Osteosarcoma } \\
\text { Renal, breast }\end{array}$ & $\begin{array}{c}{[107]} \\
{[108,109]}\end{array}$ \\
\hline & & $c-M e t$, SNAIL & miR-34a & Gastric, pancreas & {$[115,116]$} \\
\hline & HOTAIR & CCNJ & miR-205 & Bladder & [117] \\
\hline & & IGF2 & miR-663b & Pancreas & [118] \\
\hline & HOXD-AS1 & E2F8, SOX4 & miR-130a & Glioma, liver & {$[119,120]$} \\
\hline & ПUХD-ASI & FZD4 & miR-608 & Ovarian & [121] \\
\hline
\end{tabular}


Table 1. Cont

\begin{tabular}{|c|c|c|c|c|c|}
\hline Noncoding RNA Species & \multicolumn{2}{|c|}{ Competing Endogenous RNAs } & \multirow{2}{*}{$\begin{array}{c}\text { Shared miRNAs } \\
\text { miR-19b, miR-20a, miR-21, miR-26a, miR-214, miR-93, miR-106b } \\
\text { miR-17-5p }\end{array}$} & \multirow{2}{*}{$\begin{array}{c}\text { Cancer Type } \\
\text { Prostate, renal, oral, gastric } \\
\text { Esophageal }\end{array}$} & \multirow{2}{*}{$\begin{array}{c}\text { References } \\
{[31,124-126]} \\
{[127]}\end{array}$} \\
\hline \multirow{12}{*}{ Pseudogene } & PTENP1 & $\begin{array}{l}\text { PTEN } \\
\text { SOCS6 }\end{array}$ & & & \\
\hline & TUSC2P & TUSC2, TIMP2, TIMP3 & miR-17, miR-93, miR-299-3p, miR-520a, miR-608, miR-661 & Breast, prostate & [128] \\
\hline & INTS6P1 & INTS6 & miR-17-5p & Liver & [129] \\
\hline & CTNNAP1 & CTNNA & miR-141 & Colon & [130] \\
\hline & FОХОЗР & FOXO3, circ-FOXO3 & $\begin{array}{l}\text { miR-22, miR-136*, miR-138, miR-149*, miR-433, miR-762, } \\
\text { miR-3614-5p, miR-3622b-5p }\end{array}$ & Breast & [131] \\
\hline & $\begin{array}{l}\text { FTH1P11, } \\
\text { FTH1P16 }\end{array}$ & FTH1 & miR-19b, miR-181a, miR-210, miR-362, miR-616, miR-638 & Prostate & [132] \\
\hline & BRAFP1 & $B R A F$ & miR-30a, miR-182, miR-134, miR-543, miR-653, miR-876 & Melanoma & [35] \\
\hline & KRASP1 & KRAS & let-7 family & Prostate & [31] \\
\hline & $\begin{array}{l}\text { OCT4-pg1, } \\
\text { OCT4-pg3, } \\
\text { OCT4-pg4, } \\
\text { OCT4-pg5 }\end{array}$ & OCT4/POU5F1 & miR-145 & Liver, endometrial & {$[31,133,134]$} \\
\hline & RSU1P2 & IGF1R, MYCN, EPHA4 & let-7a & Cervical & [135] \\
\hline & CYP4Z2P & CYP4Z1, CDK3, hTERT & miR-125a, miR-197, miR-204, miR-1226 & Breast & [136-138] \\
\hline & HMGA1P7 & HMGA1, H19, IGF2 & miR-15, miR-16, miR-214, miR-761 & Breast & {$[139,140]$} \\
\hline \multirow{7}{*}{ CircRNA } & CDR1as & $\begin{array}{l}\text { CCNE1, PIK3CD, EGFR, } \\
\text { IGF1R, RELA }\end{array}$ & miR-7 & Liver, colon, lung, gastric & {$[144,149,151-154]$} \\
\hline & circ-ITCH & $\begin{array}{c}\text { ITCH } \\
\text { p21, PTEN }\end{array}$ & $\begin{array}{l}\text { miR-7, miR-17, miR-214 } \\
\quad \text { miR-7, miR-224 }\end{array}$ & $\begin{array}{l}\text { Lung, esophageal } \\
\text { Bladder }\end{array}$ & $\begin{array}{c}{[156,157]} \\
{[158]}\end{array}$ \\
\hline & circ-HIPK3 & $F A K, I G F 1 R, E G F R, Y Y 1$ & miR-124 & Colon & [159] \\
\hline & circ-PVT1 & $\begin{array}{l}\text { IGF2BP1, KRAS, HMGA2 } \\
\text { AURKA, MKI67, BUB1 }\end{array}$ & $\begin{array}{c}\text { let-7 } \\
\text { miR-497-5p }\end{array}$ & $\begin{array}{l}\text { Breast, lung } \\
\text { Head and neck }\end{array}$ & $\begin{array}{l}{[160]} \\
{[161]}\end{array}$ \\
\hline & circ-MYLK & VEGFA, VEGFR2 & miR-29a & Bladder & [162] \\
\hline & circ-MTO1 & $p 21$ & miR-9 & Liver & [163] \\
\hline & circ-CCDC66 & MYC & miR-93 & Colon & [164] \\
\hline
\end{tabular}


Conventional ceRNA interactions are defined by coregulation between competing partners and are highly dependent on many factors at the molecular level. However, many of the recent interactions identified have not been thoroughly validated, with some only confirmed in a unidirectional manner. In addition, predictions of MRE spacing, frequency and affinity should be performed, and the cellular abundance of the miRNA and target should also be experimentally quantified to determine the likelihood of physiological competition. Similarly, the interactions constructed using computational tools should be exhaustively tested in cells and in vivo, to confirm their efficiency and relevance in human cancers.

The recent breakthroughs in genome engineering, especially the rapid evolution of the CRISPR/ Cas9 (Clustered Regularly Interspaced Short Palindromic Repeats/CRISPR associated protein 9) system, presents an exciting opportunity to advance the ceRNA field. In the past few years, the system has been successfully adapted to target, manipulate, track and isolate RNA transcripts $[180,181]$. The discovery of the RNA-targeting nuclease Cas13 has further extended the functions of this module for effective knockdown and RNA editing of endogenous transcripts [182,183]. Abudayyeh et al. demonstrated effective knockdown KRAS, CXCR4 and PPIB (peptidylprolyl isomerase B) mRNA using Cas13a [182]. On the other hand, by fusing ADAR2 (an adenosine deaminase that catalyzes RNA A-to-I editing) to catalytically inactive Cas13b, Cox et al. were able to program RNA editing to correct disease-relevant mutations, such as G878A (AVPR2 arginine vasopressin receptor 2) in X-linked nephrogenic diabetes insipidus and G1517A (FANCC Fanconi anemia complementation group C) in Fanconi anemia [183]. Future studies could exploit this versatile system to genetically manipulate ceRNA interactions with targeted mutations and probe for physiological and endogenous interactions. It can also be used to track the movement of RNA transcripts in live cells to facilitate a more in-depth understanding of the factors governing the localization and shuttling of ncRNAs between compartments, which appear to be context-dependent and play an essential role in ceRNA interactions and cellular responses. The programmable RNA-targeting CRISPR/Cas system is an ideal platform to genetically manipulate ceRNA molecules to mechanistically and functionally dissect endogenous ceRNA networks in cancer.

Various cancer-related genes and ceRNA networks are tightly intertwined in both physiological and pathological conditions. The functional diversity of various classes of ncRNAs and the plasticity of their interactions add to the multilayered regulatory circuitry that could be derailed in malignancies. Given that ceRNA interactions generated by bioinformatics analyses have shown promising diagnostic and prognostic potential, as well as drug response predictions, this approach could be further harnessed to predict therapy resistance of specific cancers with different mutational load [174-179]. Comprehensive studies integrating computational analysis and new experimental platforms could be key to providing new insights into these complex networks. A better appreciation of the underlying mechanisms of these interactions and their role in cancer biology is essential for the development of more robust clinical tools and cancer therapies to improve patient outcome and survival. Furthermore, the conservation of different ncRNA species and ceRNA networks between human and mouse could prove valuable for "bench to bedside" translational research.

Acknowledgments: We apologize to all colleagues whose work could not be cited due to space constraints. We thank Yvonne Tay lab members (Cancer Science Institute of Singapore) for critical reading of the manuscript. This work was supported by the RNA Biology Center at the Cancer Science Institute of Singapore, National University of Singapore (NUS), as part of funding under the Singapore Ministry of Education's Tier 3 grants, grant number MOE2014-T3-1-006. Yvonne Tay was supported by a Singapore National Research Foundation Fellowship and a National University of Singapore President's Assistant Professorship.

Conflicts of Interest: The authors declare no conflict of interest. 


\section{Abbreviations}

\begin{tabular}{|c|c|}
\hline ADAR2 & adenosine deaminase, RNA specific B1 \\
\hline AGO2 & argonaute 2 , RISC catalytic component \\
\hline $\mathrm{AKT}$ & AKT serine/threonine kinase 1 / protein kinase B \\
\hline ANXA1 & annexin A1 \\
\hline AR & androgen receptor \\
\hline ARHI & DIRAS family GTPase 3 \\
\hline ATG7 & autophagy related 7 \\
\hline AVPR2 & arginine vasopressin receptor 2 \\
\hline AXL & AXL receptor tyrosine kinase \\
\hline BCL2 & B-cell lymphoma 2, apoptosis regulator \\
\hline BECN1 & beclin 1 \\
\hline $\mathrm{BMF}$ & Bcl2 modifying factor \\
\hline BRAF & B-Raf proto-oncogene, serine/threonine kinase \\
\hline BRAFP1 & B-Raf proto-oncogene, serine/threonine kinase pseudogene 1 \\
\hline BUB1 & BUB1 mitotic checkpoint serine/threonine kinase \\
\hline CCND1 & cyclin D1 \\
\hline CCNE1 & cyclin E1 \\
\hline $\mathrm{CCNJ}$ & cyclin J \\
\hline CDC42 & cell division cycle 42 \\
\hline CDK3 & cyclin dependent kinase 3 \\
\hline CDK6 & cyclin dependent kinase 6 \\
\hline ceRNA & competing endogenous RNA \\
\hline c-Kit & KIT proto-oncogene receptor tyrosine kinase \\
\hline c-Met & MET proto-oncogene, receptor tyrosine kinase \\
\hline CRC & colorectal carcinoma \\
\hline CRISPR & clustered regularly interspaced short palindromic repeats \\
\hline CTNNA1 & catenin alpha 1 \\
\hline CTNNA1P & catenin alpha 1 pseudogene \\
\hline CXCR4 & $\mathrm{C}-\mathrm{X}-\mathrm{C}$ motif chemokine receptor 4 \\
\hline CYP4Z1 & cytochrome P450 family 4 subfamily Z member 1 \\
\hline CYP4Z2P & cytochrome P450 family 4 subfamily $\mathrm{Z}$ member 2 , pseudogene \\
\hline СYTH3 & cytohesin 3 \\
\hline DNMT3B & DNA methyltransferase 3 beta \\
\hline DRCE & drug-response related ceRNA \\
\hline DVL2 & disheveled segment polarity protein 2 \\
\hline EGFR & epidermal growth factor receptor \\
\hline EGR1 & early growth response 1 \\
\hline EMT & epithelial mesenchymal transition \\
\hline EPHA4 & $\mathrm{EPH}$ receptor $\mathrm{A} 4$ \\
\hline $\mathrm{EZH} 2$ & enhancer of zeste 2 polycomb repressive complex 2 subunit \\
\hline FAK & focal adhesion kinase \\
\hline FANCC & Fanconi anemia complementation group $\mathrm{C}$ \\
\hline FASN & fatty acid synthase \\
\hline FOXO3 & forkhead box $\mathrm{O} 3$ \\
\hline FOXO3P & forkhead box O3 pseudogene \\
\hline FTH1 & ferritin heavy chain 1 \\
\hline FZD4 & frizzled class receptor 4 \\
\hline GIT2 & GIT ArfGAP 2 \\
\hline $\mathrm{HCC}$ & hepatocellular carcinoma \\
\hline HER2 & erb-b2 receptor tyrosine kinase 2 \\
\hline HIF- $1 \alpha$ & hypoxia-inducible factor 1-alpha \\
\hline HMGA1P6/7 & high mobility group AT-hook 1 pseudogene $6 / 7$ \\
\hline
\end{tabular}




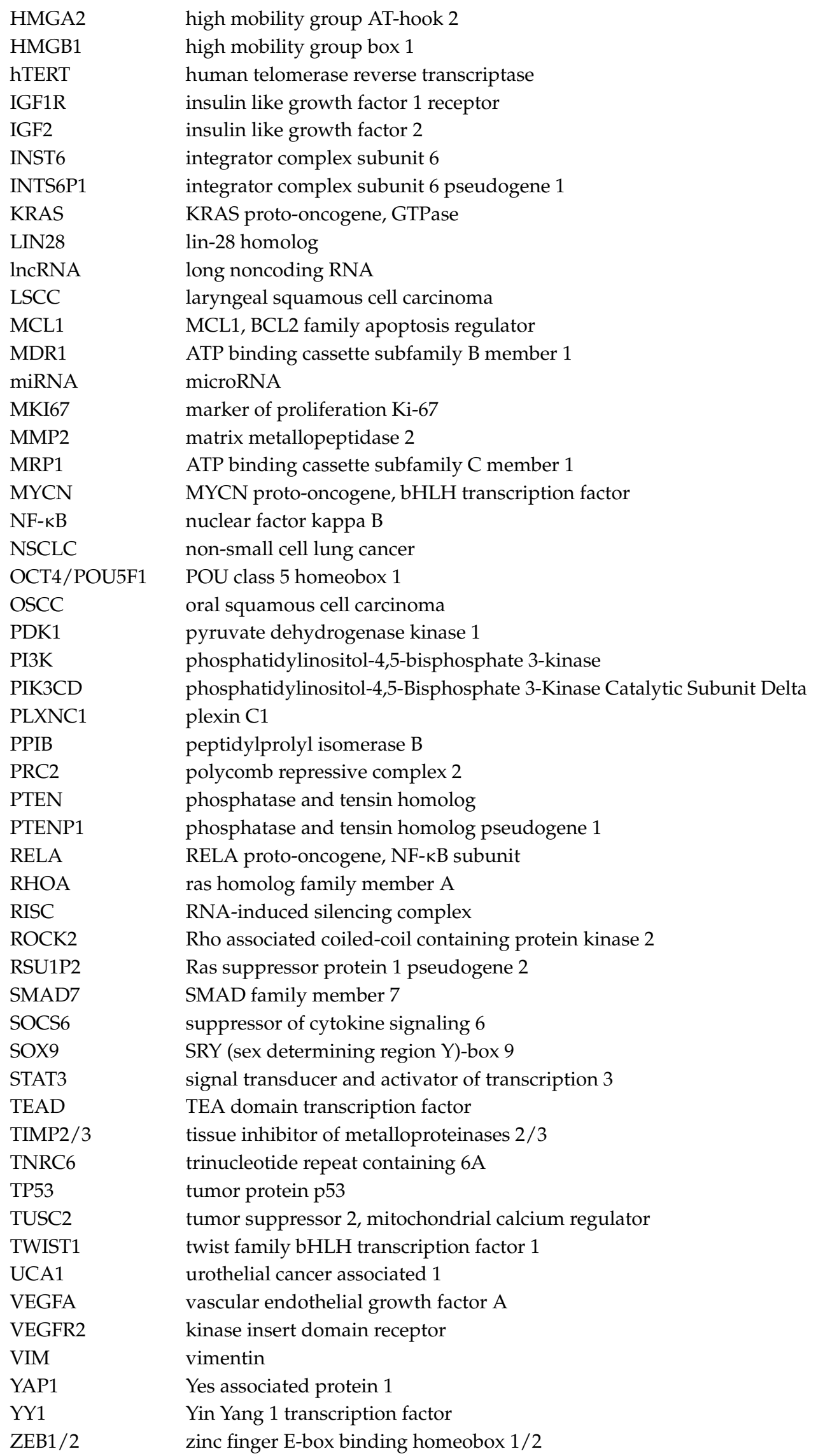




\section{References}

1. Carninci, P.; Kasukawa, T.; Katayama, S.; Gough, J.; Frith, M.C.; Maeda, N.; Oyama, R.; Ravasi, T.; Lenhard, B.; Wells, C.; et al. The transcriptional landscape of the mammalian genome. Science 2005, 309, 1559-1563. [PubMed]

2. Djebali, S.; Davis, C.A.; Merkel, A.; Dobin, A.; Lassmann, T.; Mortazavi, A.; Tanzer, A.; Lagarde, J.; Lin, W.; Schlesinger, F.; et al. Landscape of transcription in human cells. Nature 2012, 489, 101-108. [CrossRef] [PubMed]

3. Bartel, D.P.; Chen, C.Z. Micromanagers of gene expression: The potentially widespread influence of metazoan microRNAs. Nat. Rev. Genet. 2004, 5, 396-400. [CrossRef] [PubMed]

4. Guttman, M.; Rinn, J.L. Modular regulatory principles of large non-coding RNAs. Nature 2012, 482, 339-346. [CrossRef] [PubMed]

5. Cech, T.R.; Steitz, J.A. The noncoding RNA revolution-trashing old rules to forge new ones. Cell 2014, 157, 77-94. [CrossRef] [PubMed]

6. Adams, B.D.; Anastasiadou, E.; Esteller, M.; He, L.; Slack, F.J. The Inescapable Influence of Noncoding RNAs in Cancer. Cancer Res. 2015, 75, 5206-5210. [CrossRef] [PubMed]

7. Kwok, Z.H.; Tay, Y. Long noncoding RNAs: Lincs between human health and disease. Biochem. Soc. Trans. 2017, 45, 805-812. [CrossRef] [PubMed]

8. Anastasiadou, E.; Jacob, L.S.; Slack, F.J. Non-coding RNA networks in cancer. Nat. Rev. Cancer 2018, 18, 5-18. [CrossRef] [PubMed]

9. Lee, R.C.; Feinbaum, R.L.; Ambros, V. The C. elegans heterochronic gene lin-4 encodes small RNAs with antisense complementarity to lin-14. Cell 1993, 75, 843-854. [CrossRef]

10. Wightman, B.; Ha, I.; Ruvkun, G. Posttranscriptional regulation of the heterochronic gene lin-14 by lin-4 mediates temporal pattern formation in C. elegans. Cell 1993, 75, 855-862. [CrossRef]

11. Bartel, D.P. MicroRNAs: Genomics, biogenesis, mechanism, and function. Cell 2004, 116, 281-297. [CrossRef]

12. Bartel, D.P. Metazoan MicroRNAs. Cell 2018, 173, 20-51. [CrossRef] [PubMed]

13. Bracken, C.P.; Scott, H.S.; Goodall, G.J. A network-biology perspective of microRNA function and dysfunction in cancer. Nat. Rev. Genet. 2016, 17, 719-732. [CrossRef] [PubMed]

14. Svoronos, A.A.; Engelman, D.M.; Slack, F.J. OncomiR or Tumor Suppressor? The Duplicity of MicroRNAs in Cancer. Cancer Res. 2016, 76, 3666-3670. [CrossRef] [PubMed]

15. Quinn, J.J.; Chang, H.Y. Unique features of long non-coding RNA biogenesis and function. Nat. Rev. Genet. 2016, 17, 47-62. [CrossRef] [PubMed]

16. Ward, M.; McEwan, C.; Mills, J.D.; Janitz, M. Conservation and tissue-specific transcription patterns of long noncoding RNAs. J. Hum. Transcr. 2015, 1, 2-9. [CrossRef] [PubMed]

17. Li, F.; Xiao, Y.; Huang, F.; Deng, W.; Zhao, H.; Shi, X.; Wang, S.; Yu, X.; Zhang, L.; Han, Z.; et al. Spatiotemporal-specific lncRNAs in the brain, colon, liver and lung of macaque during development. Mol. Biosyst. 2015, 11, 3253-3263. [CrossRef] [PubMed]

18. Salmena, L.; Poliseno, L.; Tay, Y.; Kats, L.; Pandolfi, P.P. A ceRNA hypothesis: The Rosetta Stone of a hidden RNA language? Cell 2011, 146, 353-358. [CrossRef] [PubMed]

19. Tay, Y.; Rinn, J.; Pandolfi, P.P. The multilayered complexity of ceRNA crosstalk and competition. Nature 2014, 505, 344-352. [CrossRef] [PubMed]

20. Poliseno, L.; Marranci, A.; Pandolfi, P.P. Pseudogenes in Human Cancer. Front. Med. (Lausanne) 2015, 2, 68. [CrossRef] [PubMed]

21. Peng, Y.; Croce, C.M. The role of MicroRNAs in human cancer. Signal Transduct. Target. Ther. 2016, 1, 15004. [CrossRef] [PubMed]

22. Kristensen, L.S.; Hansen, T.B.; Veno, M.T.; Kjems, J. Circular RNAs in cancer: Opportunities and challenges in the field. Oncogene 2018, 37, 555-565. [CrossRef] [PubMed]

23. De Rie, D.; Abugessaisa, I.; Alam, T.; Arner, E.; Arner, P.; Ashoor, H.; Astrom, G.; Babina, M.; Bertin, N.; Burroughs, A.M.; et al. An integrated expression atlas of miRNAs and their promoters in human and mouse. Nat. Biotechnol. 2017, 35, 872-878. [CrossRef] [PubMed]

24. Ulitsky, I.; Bartel, D.P. LincRNAs: Genomics, evolution, and mechanisms. Cell 2013, 154, 26-46. [CrossRef] [PubMed] 
25. Brown, B.D.; Gentner, B.; Cantore, A.; Colleoni, S.; Amendola, M.; Zingale, A.; Baccarini, A.; Lazzari, G.; Galli, C.; Naldini, L. Endogenous microRNA can be broadly exploited to regulate transgene expression according to tissue, lineage and differentiation state. Nat. Biotechnol. 2007, 25, 1457-1467. [CrossRef] [PubMed]

26. Ebert, M.S.; Neilson, J.R.; Sharp, P.A. MicroRNA sponges: Competitive inhibitors of small RNAs in mammalian cells. Nat. Methods 2007, 4, 721-726. [CrossRef] [PubMed]

27. Brown, B.D.; Naldini, L. Exploiting and antagonizing microRNA regulation for therapeutic and experimental applications. Nat. Rev. Genet. 2009, 10, 578-585. [CrossRef] [PubMed]

28. Ebert, M.S.; Sharp, P.A. MicroRNA sponges: Progress and possibilities. RNA 2010, 16, 2043-2050. [CrossRef] [PubMed]

29. Franco-Zorrilla, J.M.; Valli, A.; Todesco, M.; Mateos, I.; Puga, M.I.; Rubio-Somoza, I.; Leyva, A.; Weigel, D.; Garcia, J.A.; Paz-Ares, J. Target mimicry provides a new mechanism for regulation of microRNA activity. Nat. Genet. 2007, 39, 1033-1037. [CrossRef] [PubMed]

30. Seitz, H. Redefining microRNA targets. Curr. Biol. 2009, 19, 870-873. [CrossRef] [PubMed]

31. Poliseno, L.; Salmena, L.; Zhang, J.; Carver, B.; Haveman, W.J.; Pandolfi, P.P. A coding-independent function of gene and pseudogene mRNAs regulates tumour biology. Nature 2010, 465, 1033-1038. [CrossRef] [PubMed]

32. Tay, Y.; Kats, L.; Salmena, L.; Weiss, D.; Tan, S.M.; Ala, U.; Karreth, F.; Poliseno, L.; Provero, P.; Di Cunto, F.; et al. Coding-independent regulation of the tumor suppressor PTEN by competing endogenous mRNAs. Cell 2011, 147, 344-357. [CrossRef] [PubMed]

33. Karreth, F.A.; Tay, Y.; Perna, D.; Ala, U.; Tan, S.M.; Rust, A.G.; DeNicola, G.; Webster, K.A.; Weiss, D.; Perez-Mancera, P.A.; et al. In vivo identification of tumor-suppressive PTEN ceRNAs in an oncogenic BRAF-induced mouse model of melanoma. Cell 2011, 147, 382-395. [CrossRef] [PubMed]

34. Sumazin, P.; Yang, X.; Chiu, H.S.; Chung, W.J.; Iyer, A.; Llobet-Navas, D.; Rajbhandari, P.; Bansal, M.; Guarnieri, P.; Silva, J.; et al. An extensive microRNA-mediated network of RNA-RNA interactions regulates established oncogenic pathways in glioblastoma. Cell 2011, 147, 370-381. [CrossRef] [PubMed]

35. Karreth, F.A.; Reschke, M.; Ruocco, A.; Ng, C.; Chapuy, B.; Leopold, V.; Sjoberg, M.; Keane, T.M.; Verma, A.; Ala, U.; et al. The BRAF pseudogene functions as a competitive endogenous RNA and induces lymphoma in vivo. Cell 2015, 161, 319-332. [CrossRef] [PubMed]

36. Smillie, C.L.; Sirey, T.; Ponting, C.P. Complexities of post-transcriptional regulation and the modeling of ceRNA crosstalk. Crit. Rev. Biochem. Mol. Biol. 2018. [CrossRef] [PubMed]

37. Ala, U.; Karreth, F.A.; Bosia, C.; Pagnani, A.; Taulli, R.; Leopold, V.; Tay, Y.; Provero, P.; Zecchina, R.; Pandolfi, P.P. Integrated transcriptional and competitive endogenous RNA networks are cross-regulated in permissive molecular environments. Proc. Natl. Acad. Sci. USA 2013, 110, 7154-7159. [CrossRef] [PubMed]

38. Bosson, A.D.; Zamudio, J.R.; Sharp, P.A. Endogenous miRNA and target concentrations determine susceptibility to potential ceRNA competition. Mol. Cell 2014, 56, 347-359. [CrossRef] [PubMed]

39. Denzler, R.; Agarwal, V.; Stefano, J.; Bartel, D.P.; Stoffel, M. Assessing the ceRNA hypothesis with quantitative measurements of miRNA and target abundance. Mol. Cell 2014, 54, 766-776. [CrossRef] [PubMed]

40. Denzler, R.; McGeary, S.E.; Title, A.C.; Agarwal, V.; Bartel, D.P.; Stoffel, M. Impact of MicroRNA Levels, Target-Site Complementarity, and Cooperativity on Competing Endogenous RNA-Regulated Gene Expression. Mol. Cell 2016, 64, 565-579. [CrossRef] [PubMed]

41. Powers, J.T.; Tsanov, K.M.; Pearson, D.S.; Roels, F.; Spina, C.S.; Ebright, R.; Seligson, M.; de Soysa, Y.; Cahan, P.; Theissen, J.; et al. Multiple mechanisms disrupt the let-7 microRNA family in neuroblastoma. Nature 2016, 535, 246-251. [CrossRef] [PubMed]

42. Gilot, D.; Migault, M.; Bachelot, L.; Journe, F.; Rogiers, A.; Donnou-Fournet, E.; Mogha, A.; Mouchet, N.; Pinel-Marie, M.L.; Mari, B.; et al. A non-coding function of TYRP1 mRNA promotes melanoma growth. Nat. Cell Biol. 2017, 19, 1348-1357. [CrossRef] [PubMed]

43. Brannan, C.I.; Dees, E.C.; Ingram, R.S.; Tilghman, S.M. The product of the H19 gene may function as an RNA. Mol. Cell Biol. 1990, 10, 28-36. [CrossRef] [PubMed]

44. Bartolomei, M.S.; Zemel, S.; Tilghman, S.M. Parental imprinting of the mouse H19 gene. Nature 1991, 351, 153-155. [CrossRef] [PubMed]

45. Barlow, D.P.; Stoger, R.; Herrmann, B.G.; Saito, K.; Schweifer, N. The mouse insulin-like growth factor type-2 receptor is imprinted and closely linked to the Tme locus. Nature 1991, 349, 84-87. [CrossRef] [PubMed] 
46. Borsani, G.; Tonlorenzi, R.; Simmler, M.C.; Dandolo, L.; Arnaud, D.; Capra, V.; Grompe, M.; Pizzuti, A.; Muzny, D.; Lawrence, C.; et al. Characterization of a murine gene expressed from the inactive $\mathrm{X}$ chromosome. Nature 1991, 351, 325-329. [CrossRef] [PubMed]

47. Brown, C.J.; Ballabio, A.; Rupert, J.L.; Lafreniere, R.G.; Grompe, M.; Tonlorenzi, R.; Willard, H.F. A gene from the region of the human $X$ inactivation centre is expressed exclusively from the inactive $X$ chromosome. Nature 1991, 349, 38-44. [CrossRef] [PubMed]

48. Brockdorff, N.; Ashworth, A.; Kay, G.F.; Cooper, P.; Smith, S.; McCabe, V.M.; Norris, D.P.; Penny, G.D.; Patel, D.; Rastan, S. Conservation of position and exclusive expression of mouse Xist from the inactive $\mathrm{X}$ chromosome. Nature 1991, 351, 329-331. [CrossRef] [PubMed]

49. Kopp, F.; Mendell, J.T. Functional Classification and Experimental Dissection of Long Noncoding RNAs. Cell 2018, 172, 393-407. [CrossRef] [PubMed]

50. Rachmilewitz, J.; Goshen, R.; Ariel, I.; Schneider, T.; de Groot, N.; Hochberg, A. Parental imprinting of the human H19 gene. FEBS Lett. 1992, 309, 25-28. [CrossRef]

51. Park, I.Y.; Sohn, B.H.; Choo, J.H.; Joe, C.O.; Seong, J.K.; Lee, Y.I.; Chung, J.H. Deregulation of DNA methyltransferases and loss of parental methylation at the insulin-like growth factor II (Igf2)/H19 loci in p53 knockout mice prior to tumor development. J. Cell. Biochem. 2005, 94, 585-596. [CrossRef] [PubMed]

52. Shoshani, O.; Massalha, H.; Shani, N.; Kagan, S.; Ravid, O.; Madar, S.; Trakhtenbrot, L.; Leshkowitz, D.; Rechavi, G.; Zipori, D. Polyploidization of murine mesenchymal cells is associated with suppression of the long noncoding RNA H19 and reduced tumorigenicity. Cancer Res. 2012, 72, 6403-6413. [CrossRef] [PubMed]

53. Raveh, E.; Matouk, I.J.; Gilon, M.; Hochberg, A. The H19 Long non-coding RNA in cancer initiation, progression and metastasis-A proposed unifying theory. Mol. Cancer 2015, 14, 184. [CrossRef] [PubMed]

54. Lv, M.; Zhong, Z.; Huang, M.; Tian, Q.; Jiang, R.; Chen, J. lncRNA H19 regulates epithelial-mesenchymal transition and metastasis of bladder cancer by miR-29b-3p as competing endogenous RNA. Biochim. Biophys. Acta 2017, 1864, 1887-1899. [CrossRef] [PubMed]

55. Zhou, W.; Ye, X.L.; Xu, J.; Cao, M.G.; Fang, Z.Y.; Li, L.Y.; Guan, G.H.; Liu, Q.; Qian, Y.H.; Xie, D. The lncRNA H19 mediates breast cancer cell plasticity during EMT and MET plasticity by differentially sponging miR-200b/c and let-7b. Sci. Signal. 2017, 10. [CrossRef] [PubMed]

56. Ma, C.; Nong, K.; Zhu, H.; Wang, W.; Huang, X.; Yuan, Z.; Ai, K. H19 promotes pancreatic cancer metastasis by derepressing let-7's suppression on its target HMGA2-mediated EMT. Tumour Biol. 2014, 35, 9163-9169. [CrossRef] [PubMed]

57. Kou, N.; Liu, S.; Li, X.; Li, W.; Zhong, W.; Gui, L.; Chai, S.; Ren, X.; Na, R.; Zeng, T.; et al. H19 facilitates tongue squamous cell carcinoma migration and invasion via sponging miR-let-7. Oncol. Res. 2018. [CrossRef] [PubMed]

58. Liang, W.C.; Fu, W.M.; Wong, C.W.; Wang, Y.; Wang, W.M.; Hu, G.X.; Zhang, L.; Xiao, L.J.; Wan, D.C.; Zhang, J.F.; et al. The lncRNA H19 promotes epithelial to mesenchymal transition by functioning as miRNA sponges in colorectal cancer. Oncotarget 2015, 6, 22513-22525. [CrossRef] [PubMed]

59. Zhang, Q.; Li, X.; Li, X.; Li, X.; Chen, Z. LncRNA H19 promotes epithelial-mesenchymal transition (EMT) by targeting miR-484 in human lung cancer cells. J. Cell. Biochem. 2018, 119, 4447-4457. [CrossRef] [PubMed]

60. Kallen, A.N.; Zhou, X.B.; Xu, J.; Qiao, C.; Ma, J.; Yan, L.; Lu, L.; Liu, C.; Yi, J.S.; Zhang, H.; et al. The imprinted H19 lncRNA antagonizes let-7 microRNAs. Mol. Cell 2013, 52, 101-112. [CrossRef] [PubMed]

61. Peng, F.; Li, T.T.; Wang, K.L.; Xiao, G.Q.; Wang, J.H.; Zhao, H.D.; Kang, Z.J.; Fan, W.J.; Zhu, L.L.; Li, M.; et al. H19/let-7/LIN28 reciprocal negative regulatory circuit promotes breast cancer stem cell maintenance. Cell Death Dis. 2017, 8, e2569. [CrossRef] [PubMed]

62. Yu, X.; Li, Z. Long non-coding RNA growth arrest-specific transcript 5 in tumor biology. Oncol. Lett. 2015, 10, 1953-1958. [CrossRef] [PubMed]

63. Zhang, X.F.; Ye, Y.; Zhao, S.J. LncRNA Gas5 acts as a ceRNA to regulate PTEN expression by sponging miR-222-3p in papillary thyroid carcinoma. Oncotarget 2018, 9, 3519-3530. [CrossRef] [PubMed]

64. Li, Y.; Gu, J.; Lu, H. The GAS5/miR-222 Axis Regulates Proliferation of Gastric Cancer Cells through the PTEN/Akt/mTOR Pathway. Dig. Dis. Sci. 2017, 62, 3426-3437. [CrossRef] [PubMed]

65. Guo, C.; Song, W.Q.; Sun, P.; Jin, L.; Dai, H.Y. LncRNA-GAS5 induces PTEN expression through inhibiting miR-103 in endometrial cancer cells. J. Biomed. Sci. 2015, 22, 100. [CrossRef] [PubMed] 
66. Wen, Q.; Liu, Y.; Lyu, H.; Xu, X.; Wu, Q.; Liu, N.; Yin, Q.; Li, J.; Sheng, X. Long Noncoding RNA GAS5, Which Acts as a Tumor Suppressor via microRNA 21, Regulates Cisplatin Resistance Expression in Cervical Cancer. Int. J. Gynecol. Cancer 2017, 27, 1096-1108. [CrossRef] [PubMed]

67. Cao, L.; Chen, J.; Ou, B.; Liu, C.; Zou, Y.; Chen, Q. GAS5 knockdown reduces the chemo-sensitivity of non-small cell lung cancer (NSCLC) cell to cisplatin (DDP) through regulating miR-21/PTEN axis. Biomed. Pharmacother. 2017, 93, 570-579. [CrossRef] [PubMed]

68. Li, W.; Zhao, W.; Lu, Z.; Zhang, W.; Yang, X. Long non-coding RNA GAS5 promotes proliferation, migration and invasion by regulation of miR-301a in esophageal cancer. Oncol. Res. 2018. [CrossRef] [PubMed]

69. Loewer, S.; Cabili, M.N.; Guttman, M.; Loh, Y.H.; Thomas, K.; Park, I.H.; Garber, M.; Curran, M.; Onder, T.; Agarwal, S.; et al. Large intergenic non-coding RNA-RoR modulates reprogramming of human induced pluripotent stem cells. Nat. Genet. 2010, 42, 1113-1117. [CrossRef] [PubMed]

70. Wang, Y.; Xu, Z.; Jiang, J.; Xu, C.; Kang, J.; Xiao, L.; Wu, M.; Xiong, J.; Guo, X.; Liu, H. Endogenous miRNA sponge lincRNA-RoR regulates Oct4, Nanog, and Sox2 in human embryonic stem cell self-renewal. Dev. Cell 2013, 25, 69-80. [CrossRef] [PubMed]

71. Fu, Z.; Li, G.; Li, Z.; Wang, Y.; Zhao, Y.; Zheng, S.; Ye, H.; Luo, Y.; Zhao, X.; Wei, L.; et al. Endogenous miRNA Sponge LincRNA-ROR promotes proliferation, invasion and stem cell-like phenotype of pancreatic cancer cells. Cell Death Discov. 2017, 3, 17004. [CrossRef] [PubMed]

72. Wang, L.; Yu, X.; Zhang, Z.; Pang, L.; Xu, J.; Jiang, J.; Liang, W.; Chai, Y.; Hou, J.; Li, F. Linc-ROR promotes esophageal squamous cell carcinoma progression through the derepression of SOX9. J. Exp. Clin. Cancer Res. 2017, 36, 182. [CrossRef] [PubMed]

73. Lee, S.; Kopp, F.; Chang, T.C.; Sataluri, A.; Chen, B.; Sivakumar, S.; Yu, H.; Xie, Y.; Mendell, J.T. Noncoding RNA NORAD Regulates Genomic Stability by Sequestering PUMILIO Proteins. Cell 2016, 164, 69-80. [CrossRef] [PubMed]

74. Li, H.; Wang, X.; Wen, C.; Huo, Z.; Wang, W.; Zhan, Q.; Cheng, D.; Chen, H.; Deng, X.; Peng, C.; et al. Long noncoding RNA NORAD, a novel competing endogenous RNA, enhances the hypoxia-induced epithelial-mesenchymal transition to promote metastasis in pancreatic cancer. Mol. Cancer 2017, 16, 169. [CrossRef] [PubMed]

75. Ng, K.; Pullirsch, D.; Leeb, M.; Wutz, A. Xist and the order of silencing. EMBO Rep. 2007, 8, 34-39. [CrossRef] [PubMed]

76. Zhuang, L.K.; Yang, Y.T.; Ma, X.; Han, B.; Wang, Z.S.; Zhao, Q.Y.; Wu, L.Q.; Qu, Z.Q. MicroRNA-92b promotes hepatocellular carcinoma progression by targeting Smad7 and is mediated by long non-coding RNA XIST. Cell Death Dis. 2016, 7, e2203. [CrossRef] [PubMed]

77. Chang, S.; Chen, B.; Wang, X.; Wu, K.; Sun, Y. Long non-coding RNA XIST regulates PTEN expression by sponging miR-181a and promotes hepatocellular carcinoma progression. BMC Cancer 2017, 17, 248. [CrossRef] [PubMed]

78. Mo, Y.; Lu, Y.; Wang, P.; Huang, S.; He, L.; Li, D.; Li, F.; Huang, J.; Lin, X.; Li, X.; et al. Long non-coding RNA XIST promotes cell growth by regulating miR-139-5p/PDK1/AKT axis in hepatocellular carcinoma. Tumour Biol. 2017, 39. [CrossRef] [PubMed]

79. Chen, D.L.; Ju, H.Q.; Lu, Y.X.; Chen, L.Z.; Zeng, Z.L.; Zhang, D.S.; Luo, H.Y.; Wang, F.; Qiu, M.Z.; Wang, D.S.; et al. Long non-coding RNA XIST regulates gastric cancer progression by acting as a molecular sponge of miR-101 to modulate EZH2 expression. J. Exp. Clin. Cancer Res. 2016, 35, 142. [CrossRef] [PubMed]

80. Xiong, Y.; Wang, L.; Li, Y.; Chen, M.; He, W.; Qi, L. The Long Non-Coding RNA XIST Interacted with MiR-124 to Modulate Bladder Cancer Growth, Invasion and Migration by Targeting Androgen Receptor (AR). Cell. Physiol. Biochem. 2017, 43, 405-418. [CrossRef] [PubMed]

81. Wei, W.; Liu, Y.; Lu, Y.; Yang, B.; Tang, L. LncRNA XIST Promotes Pancreatic Cancer Proliferation through miR-133a/EGFR. J. Cell. Biochem. 2017, 118, 3349-3358. [CrossRef] [PubMed]

82. Brockdorff, N. Polycomb complexes in X chromosome inactivation. Philos. Trans. R. Soc. Lond. B Biol. Sci. 2017, 372. [CrossRef] [PubMed]

83. Sunwoo, H.; Dinger, M.E.; Wilusz, J.E.; Amaral, P.P.; Mattick, J.S.; Spector, D.L. MEN epsilon/beta nuclear-retained non-coding RNAs are up-regulated upon muscle differentiation and are essential components of paraspeckles. Genome Res. 2009, 19, 347-359. [CrossRef] [PubMed] 
84. Clemson, C.M.; Hutchinson, J.N.; Sara, S.A.; Ensminger, A.W.; Fox, A.H.; Chess, A.; Lawrence, J.B. An architectural role for a nuclear noncoding RNA: NEAT1 RNA is essential for the structure of paraspeckles. Mol. Cell 2009, 33, 717-726. [CrossRef] [PubMed]

85. Wang, P.; Wu, T.; Zhou, H.; Jin, Q.; He, G.; Yu, H.; Xuan, L.; Wang, X.; Tian, L.; Sun, Y.; et al. Long noncoding RNA NEAT1 promotes laryngeal squamous cell cancer through regulating miR-107/CDK6 pathway. J. Exp. Clin. Cancer Res. 2016, 35, 22. [CrossRef] [PubMed]

86. Yang, X.; Xiao, Z.; Du, X.; Huang, L.; Du, G. Silencing of the long non-coding RNA NEAT1 suppresses glioma stem-like properties through modulation of the miR-107/CDK6 pathway. Oncol. Rep. 2017, 37, 555-562. [CrossRef] [PubMed]

87. Tan, H.Y.; Wang, C.; Liu, G.; Zhou, X. Long noncoding RNA NEAT1-modualted miR-506 regulates gastric cancer development through targeting STAT3. J. Cell. Biochem. 2018. [CrossRef] [PubMed]

88. Gong, W.; Zheng, J.; Liu, X.; Ma, J.; Liu, Y.; Xue, Y. Knockdown of NEAT1 restrained the malignant progression of glioma stem cells by activating microRNA let-7e. Oncotarget 2016, 7, 62208-62223. [CrossRef] [PubMed]

89. Lu, Y.; Li, T.; Wei, G.; Liu, L.; Chen, Q.; Xu, L.; Zhang, K.; Zeng, D.; Liao, R. The long non-coding RNA NEAT1 regulates epithelial to mesenchymal transition and radioresistance in through miR-204/ZEB1 axis in nasopharyngeal carcinoma. Tumour Biol. 2016, 37, 11733-11741. [CrossRef] [PubMed]

90. Han, D.; Wang, J.; Cheng, G. LncRNA NEAT1 enhances the radio-resistance of cervical cancer via miR-193b-3p/CCND1 axis. Oncotarget 2018, 9, 2395-2409. [CrossRef] [PubMed]

91. Hutchinson, J.N.; Ensminger, A.W.; Clemson, C.M.; Lynch, C.R.; Lawrence, J.B.; Chess, A. A screen for nuclear transcripts identifies two linked noncoding RNAs associated with SC35 splicing domains. BMC Genom. 2007, 8, 39. [CrossRef] [PubMed]

92. Gutschner, T.; Hammerle, M.; Eissmann, M.; Hsu, J.; Kim, Y.; Hung, G.; Revenko, A.; Arun, G.; Stentrup, M.; Gross, M.; et al. The noncoding RNA MALAT1 is a critical regulator of the metastasis phenotype of lung cancer cells. Cancer Res. 2013, 73, 1180-1189. [CrossRef] [PubMed]

93. Liu, J.; Peng, W.X.; Mo, Y.Y.; Luo, D. MALAT1-mediated tumorigenesis. Front. Biosci. 2017, 22, $66-80$.

94. Jie, Y.; Zhao, H.; Meng, W.-Y.; Wu, Q. LncRNA MALAT1 induces colon cancer development by regulating miR-129-5p/HMGB1 axis. J. Cell. Physiol. 2018. [CrossRef]

95. Chou, J.; Wang, B.; Zheng, T.; Li, X.; Zheng, L.; Hu, J.; Zhang, Y.; Xing, Y.; Xi, T. MALAT1 induced migration and invasion of human breast cancer cells by competitively binding miR-1 with cdc42. Biochem. Biophys. Res. Commun. 2016, 472, 262-269. [CrossRef] [PubMed]

96. Wang, S.H.; Zhang, W.J.; Wu, X.C.; Zhang, M.D.; Weng, M.Z.; Zhou, D.; Wang, J.D.; Quan, Z.W. Long non-coding RNA Malat1 promotes gallbladder cancer development by acting as a molecular sponge to regulate miR-206. Oncotarget 2016, 7, 37857-37867. [CrossRef] [PubMed]

97. Li, S.; Mei, Z.; Hu, H.B.; Zhang, X. The lncRNA MALAT1 contributes to non-small cell lung cancer development via modulating miR-124/STAT3 axis. J. Cell. Physiol. 2017. [CrossRef] [PubMed]

98. Chang, S.M.; Hu, W.W. Long non-coding RNA MALAT1 promotes oral squamous cell carcinoma development via microRNA-125b/STAT3 axis. J. Cell. Physiol. 2018, 233, 3384-3396. [CrossRef] [PubMed]

99. Fang, Z.; Chen, W.; Yuan, Z.; Liu, X.; Jiang, H. LncRNA-MALAT1 contributes to the cisplatin-resistance of lung cancer by upregulating MRP1 and MDR1 via STAT3 activation. Biomed. Pharmacother. 2018, 101, 536-542. [CrossRef] [PubMed]

100. Kwok, Z.H.; Roche, V.; Chew, X.H.; Fadieieva, A.; Tay, Y. A non-canonical tumor suppressive role for the long non-coding RNA MALAT1 in colon and breast cancers. Int. J. Cancer 2018. [CrossRef] [PubMed]

101. Tseng, Y.Y.; Moriarity, B.S.; Gong, W.; Akiyama, R.; Tiwari, A.; Kawakami, H.; Ronning, P.; Reuland, B.; Guenther, K.; Beadnell, T.C.; et al. PVT1 dependence in cancer with MYC copy-number increase. Nature 2014, 512, 82-86. [CrossRef] [PubMed]

102. Lan, T.; Yan, X.; Li, Z.; Xu, X.; Mao, Q.; Ma, W.; Hong, Z.; Chen, X.; Yuan, Y. Long non-coding RNA PVT1 serves as a competing endogenous RNA for miR-186-5p to promote the tumorigenesis and metastasis of hepatocellular carcinoma. Tumour Biol. 2017, 39. [CrossRef] [PubMed]

103. Huang, T.; Liu, H.W.; Chen, J.Q.; Wang, S.H.; Hao, L.Q.; Liu, M.; Wang, B. The long noncoding RNA PVT1 functions as a competing endogenous RNA by sponging miR-186 in gastric cancer. Biomed. Pharmacother. 2017, 88, 302-308. [CrossRef] [PubMed]

104. Ma, Y.; Wang, P.; Xue, Y.; Qu, C.; Zheng, J.; Liu, X.; Ma, J.; Liu, Y. PVT1 affects growth of glioma microvascular endothelial cells by negatively regulating miR-186. Tumour Biol. 2017, 39. [CrossRef] [PubMed] 
105. Chang, Z.; Cui, J.; Song, Y. Long noncoding RNA PVT1 promotes EMT via mediating microRNA-186 targeting of Twist1 in prostate cancer. Gene 2018, 654, 36-42. [CrossRef] [PubMed]

106. Wang, C.; Han, C.; Zhang, Y.; Liu, F. LncRNA PVT1 regulate expression of HIF1alpha via functioning as ceRNA for miR199a5p in nonsmall cell lung cancer under hypoxia. Mol. Med. Rep. 2018, 17, 1105-1110. [PubMed]

107. Zhou, Q.; Chen, F.; Zhao, J.; Li, B.; Liang, Y.; Pan, W.; Zhang, S.; Wang, X.; Zheng, D. Long non-coding RNA PVT1 promotes osteosarcoma development by acting as a molecular sponge to regulate miR-195. Oncotarget 2016, 7, 82620-82633. [CrossRef] [PubMed]

108. Yang, T.; Zhou, H.; Liu, P.; Yan, L.; Yao, W.; Chen, K.; Zeng, J.; Li, H.; Hu, J.; Xu, H.; et al. IncRNA PVT1 and its splicing variant function as competing endogenous RNA to regulate clear cell renal cell carcinoma progression. Oncotarget 2017, 8, 85353-85367. [CrossRef] [PubMed]

109. Conte, F.; Fiscon, G.; Chiara, M.; Colombo, T.; Farina, L.; Paci, P. Role of the long non-coding RNA PVT1 in the dysregulation of the ceRNA-ceRNA network in human breast cancer. PLoS ONE 2017, 12, e0171661. [CrossRef] [PubMed]

110. Zhang, S.; Zhang, G.; Liu, J. Long noncoding RNA PVT1 promotes cervical cancer progression through epigenetically silencing miR-200b. APMIS 2016, 124, 649-658. [CrossRef] [PubMed]

111. Huppi, K.; Volfovsky, N.; Runfola, T.; Jones, T.L.; Mackiewicz, M.; Martin, S.E.; Mushinski, J.F.; Stephens, R.; Caplen, N.J. The identification of microRNAs in a genomically unstable region of human chromosome 8q24. Mol. Cancer Res. 2008, 6, 212-221. [CrossRef] [PubMed]

112. Cui, M.; You, L.; Ren, X.; Zhao, W.; Liao, Q.; Zhao, Y. Long non-coding RNA PVT1 and cancer. Biochem. Biophys. Res. Commun. 2016, 471, 10-14. [CrossRef] [PubMed]

113. Rinn, J.L.; Kertesz, M.; Wang, J.K.; Squazzo, S.L.; Xu, X.; Brugmann, S.A.; Goodnough, L.H.; Helms, J.A.; Farnham, P.J.; Segal, E.; et al. Functional demarcation of active and silent chromatin domains in human HOX loci by noncoding RNAs. Cell 2007, 129, 1311-1323. [CrossRef] [PubMed]

114. Tsai, M.C.; Manor, O.; Wan, Y.; Mosammaparast, N.; Wang, J.K.; Lan, F.; Shi, Y.; Segal, E.; Chang, H.Y. Long noncoding RNA as modular scaffold of histone modification complexes. Science 2010, 329, 689-693. [CrossRef] [PubMed]

115. Liu, Y.W.; Sun, M.; Xia, R.; Zhang, E.B.; Liu, X.H.; Zhang, Z.H.; Xu, T.P.; De, W.; Liu, B.R.; Wang, Z.X. LincHOTAIR epigenetically silences miR34a by binding to PRC2 to promote the epithelial-to-mesenchymal transition in human gastric cancer. Cell Death Dis. 2015, 6, e1802. [CrossRef] [PubMed]

116. Li, C.H.; Xiao, Z.; Tong, J.H.; To, K.F.; Fang, X.; Cheng, A.S.; Chen, Y. EZH2 coupled with HOTAIR to silence MicroRNA-34a by the induction of heterochromatin formation in human pancreatic ductal adenocarcinoma. Int. J. Cancer 2017, 140, 120-129. [CrossRef] [PubMed]

117. Sun, X.; Du, P.; Yuan, W.; Du, Z.; Yu, M.; Yu, X.; Hu, T. Long non-coding RNA HOTAIR regulates cyclin J via inhibition of microRNA-205 expression in bladder cancer. Cell Death Dis. 2015, 6, e1907. [CrossRef] [PubMed]

118. Cai, H.; An, Y.; Chen, X.; Sun, D.; Chen, T.; Peng, Y.; Zhu, F.; Jiang, Y.; He, X. Epigenetic inhibition of miR-663b by long non-coding RNA HOTAIR promotes pancreatic cancer cell proliferation via up-regulation of insulin-like growth factor 2. Oncotarget 2016, 7, 86857-86870. [CrossRef] [PubMed]

119. Chen, Y.; Zhao, F.; Cui, D.; Jiang, R.; Chen, J.; Huang, Q.; Shi, J. HOXD-AS1/miR-130a sponge regulates glioma development by targeting E2F8. Int. J. Cancer 2018, 142, 2313-2322. [CrossRef] [PubMed]

120. Wang, H.; Huo, X.; Yang, X.R.; He, J.; Cheng, L.; Wang, N.; Deng, X.; Jin, H.; Wang, N.; Wang, C.; et al. STAT3-mediated upregulation of lncRNA HOXD-AS1 as a ceRNA facilitates liver cancer metastasis by regulating SOX4. Mol. Cancer 2017, 16, 136. [CrossRef] [PubMed]

121. Wang, Y.; Zhang, W.; Wang, Y.; Wang, S. HOXD-AS1 promotes cell proliferation, migration and invasion through miR-608/FZD4 axis in ovarian cancer. Am. J. Cancer Res. 2018, 8, 170-182. [PubMed]

122. Zhang, Z.; Harrison, P.M.; Liu, Y.; Gerstein, M. Millions of years of evolution preserved: A comprehensive catalog of the processed pseudogenes in the human genome. Genome Res. 2003, 13, 2541-2558. [CrossRef] [PubMed]

123. Kim, M.S.; Pinto, S.M.; Getnet, D.; Nirujogi, R.S.; Manda, S.S.; Chaerkady, R.; Madugundu, A.K.; Kelkar, D.S.; Isserlin, R.; Jain, S.; et al. A draft map of the human proteome. Nature 2014, 509, 575-581. [CrossRef] [PubMed]

124. Yu, G.; Yao, W.; Gumireddy, K.; Li, A.; Wang, J.; Xiao, W.; Chen, K.; Xiao, H.; Li, H.; Tang, K.; et al. Pseudogene PTENP1 functions as a competing endogenous RNA to suppress clear-cell renal cell carcinoma progression. Mol. Cancer Ther. 2014, 13, 3086-3097. [CrossRef] [PubMed] 
125. Gao, L.; Ren, W.; Zhang, L.; Li, S.; Kong, X.; Zhang, H.; Dong, J.; Cai, G.; Jin, C.; Zheng, D.; et al. PTENp1, a natural sponge of miR-21, mediates PTEN expression to inhibit the proliferation of oral squamous cell carcinoma. Mol. Carcinog. 2017, 56, 1322-1334. [CrossRef] [PubMed]

126. Zhang, R.; Guo, Y.; Ma, Z.; Ma, G.; Xue, Q.; Li, F.; Liu, L. Long non-coding RNA PTENP1 functions as a ceRNA to modulate PTEN level by decoying miR-106b and miR-93 in gastric cancer. Oncotarget 2017, 8, 26079-26089. [CrossRef] [PubMed]

127. Gong, T.; Zheng, S.; Huang, S.; Fu, S.; Zhang, X.; Pan, S.; Yang, T.; Sun, Y.; Wang, Y.; Hui, B.; et al. PTENP1 inhibits the growth of esophageal squamous cell carcinoma by regulating SOCS6 expression and correlates with disease prognosis. Mol. Carcinog. 2017, 56, 2610-2619. [CrossRef] [PubMed]

128. Rutnam, Z.J.; Du, W.W.; Yang, W.; Yang, X.; Yang, B.B. The pseudogene TUSC2P promotes TUSC2 function by binding multiple microRNAs. Nat. Commun. 2014, 5, 2914. [CrossRef] [PubMed]

129. Peng, H.; Ishida, M.; Li, L.; Saito, A.; Kamiya, A.; Hamilton, J.P.; Fu, R.; Olaru, A.V.; An, F.; Popescu, I.; et al. Pseudogene INTS6P1 regulates its cognate gene INTS6 through competitive binding of miR-17-5p in hepatocellular carcinoma. Oncotarget 2015, 6, 5666-5677. [CrossRef] [PubMed]

130. Chen, X.; Zhu, H.; Wu, X.; Xie, X.; Huang, G.; Xu, X.; Li, S.; Xing, C. Downregulated pseudogene CTNNAP1 promote tumor growth in human cancer by downregulating its cognate gene CTNNA1 expression. Oncotarget 2016, 7, 55518-55528. [CrossRef] [PubMed]

131. Yang, W.; Du, W.W.; Li, X.; Yee, A.J.; Yang, B.B. Foxo3 activity promoted by non-coding effects of circular RNA and Foxo3 pseudogene in the inhibition of tumor growth and angiogenesis. Oncogene 2016, 35, 3919-3931. [CrossRef] [PubMed]

132. Chan, J.J.; Kwok, Z.H.; Chew, X.H.; Zhang, B.; Liu, C.; Soong, T.W.; Yang, H.; Tay, Y. A FTH1 gene:pseudogene:microRNA network regulates tumorigenesis in prostate cancer. Nucleic Acids Res. 2018, 46, 1998-2011. [CrossRef] [PubMed]

133. Wang, L.; Guo, Z.Y.; Zhang, R.; Xin, B.; Chen, R.; Zhao, J.; Wang, T.; Wen, W.H.; Jia, L.T.; Yao, L.B.; et al. Pseudogene OCT4-pg4 functions as a natural micro RNA sponge to regulate OCT4 expression by competing for miR-145 in hepatocellular carcinoma. Carcinogenesis 2013, 34, 1773-1781. [CrossRef] [PubMed]

134. Bai, M.; Yuan, M.; Liao, H.; Chen, J.; Xie, B.; Yan, D.; Xi, X.; Xu, X.; Zhang, Z.; Feng, Y. OCT4 pseudogene 5 upregulates OCT4 expression to promote proliferation by competing with miR-145 in endometrial carcinoma. Oncol. Rep. 2015, 33, 1745-1752. [CrossRef] [PubMed]

135. Liu, Q.; Guo, X.; Que, S.; Yang, X.; Fan, H.; Liu, M.; Li, X.; Tang, H. LncRNA RSU1P2 contributes to tumorigenesis by acting as a ceRNA against let-7a in cervical cancer cells. Oncotarget 2017, 8, 43768-43781. [CrossRef] [PubMed]

136. Zheng, L.; Li, X.; Gu, Y.; Lv, X.; Xi, T. The 3'UTR of the pseudogene CYP4Z2P promotes tumor angiogenesis in breast cancer by acting as a ceRNA for CYP4Z1. Breast Cancer Res. Treat. 2015, 150, 105-118. [CrossRef] [PubMed]

137. Zheng, L.; Li, X.; Meng, X.; Chou, J.; Hu, J.; Zhang, F.; Zhang, Z.; Xing, Y.; Liu, Y.; Xi, T. Competing endogenous RNA networks of CYP4Z1 and pseudogene CYP4Z2P confer tamoxifen resistance in breast cancer. Mol. Cell. Endocrinol. 2016, 427, 133-142. [CrossRef] [PubMed]

138. Li, C.; Zheng, L.; Xin, Y.; Tan, Z.; Zhang, Y.; Meng, X.; Wang, Z.; Xi, T. The competing endogenous RNA network of CYP4Z1 and pseudogene CYP4Z2P exerts an anti-apoptotic function in breast cancer. FEBS Lett. 2017, 591, 991-1000. [CrossRef] [PubMed]

139. De Martino, M.; Forzati, F.; Marfella, M.; Pellecchia, S.; Arra, C.; Terracciano, L.; Fusco, A.; Esposito, F. HMGA1P7-pseudogene regulates H19 and Igf2 expression by a competitive endogenous RNA mechanism. Sci. Rep. 2016, 6, 37622. [CrossRef] [PubMed]

140. De Martino, M.; Palma, G.; Azzariti, A.; Arra, C.; Fusco, A.; Esposito, F. The HMGA1 Pseudogene 7 Induces miR-483 and miR-675 Upregulation by Activating Egr1 through a ceRNA Mechanism. Genes 2017, 8, 330. [CrossRef] [PubMed]

141. Cocquerelle, C.; Mascrez, B.; Hetuin, D.; Bailleul, B. Mis-splicing yields circular RNA molecules. FASEB J. 1993, 7, 155-160. [CrossRef] [PubMed]

142. Salzman, J.; Gawad, C.; Wang, P.L.; Lacayo, N.; Brown, P.O. Circular RNAs are the predominant transcript isoform from hundreds of human genes in diverse cell types. PLoS ONE 2012, 7, e30733. [CrossRef] [PubMed]

143. Jeck, W.R.; Sorrentino, J.A.; Wang, K.; Slevin, M.K.; Burd, C.E.; Liu, J.; Marzluff, W.F.; Sharpless, N.E. Circular RNAs are abundant, conserved, and associated with ALU repeats. RNA 2013, 19, 141-157. [CrossRef] [PubMed] 
144. Memczak, S.; Jens, M.; Elefsinioti, A.; Torti, F.; Krueger, J.; Rybak, A.; Maier, L.; Mackowiak, S.D.; Gregersen, L.H.; Munschauer, M.; et al. Circular RNAs are a large class of animal RNAs with regulatory potency. Nature 2013, 495, 333-338. [CrossRef] [PubMed]

145. Guo, J.U.; Agarwal, V.; Guo, H.; Bartel, D.P. Expanded identification and characterization of mammalian circular RNAs. Genome Biol. 2014, 15, 409. [CrossRef] [PubMed]

146. Zheng, Q.; Bao, C.; Guo, W.; Li, S.; Chen, J.; Chen, B.; Luo, Y.; Lyu, D.; Li, Y.; Shi, G.; et al. Circular RNA profiling reveals an abundant circHIPK3 that regulates cell growth by sponging multiple miRNAs. Nat. Commun. 2016, 7, 11215. [CrossRef] [PubMed]

147. Jeck, W.R.; Sharpless, N.E. Detecting and characterizing circular RNAs. Nat. Biotechnol. 2014, 32, $453-461$. [CrossRef] [PubMed]

148. Chen, L.L. The biogenesis and emerging roles of circular RNAs. Nat. Rev. Mol. Cell Biol. 2016, 17, $205-211$. [CrossRef] [PubMed]

149. Hansen, T.B.; Kjems, J.; Damgaard, C.K. Circular RNA and miR-7 in cancer. Cancer Res. 2013, 73, 5609-5612. [CrossRef] [PubMed]

150. Piwecka, M.; Glazar, P.; Hernandez-Miranda, L.R.; Memczak, S.; Wolf, S.A.; Rybak-Wolf, A.; Filipchyk, A.; Klironomos, F.; Cerda Jara, C.A.; Fenske, P.; et al. Loss of a mammalian circular RNA locus causes miRNA deregulation and affects brain function. Science 2017, 357. [CrossRef] [PubMed]

151. Yu, L.; Gong, X.; Sun, L.; Zhou, Q.; Lu, B.; Zhu, L. The Circular RNA Cdr1as Act as an Oncogene in Hepatocellular Carcinoma through Targeting miR-7 Expression. PLoS ONE 2016, 11, e0158347. [CrossRef] [PubMed]

152. Tang, W.; Ji, M.; He, G.; Yang, L.; Niu, Z.; Jian, M.; Wei, Y.; Ren, L.; Xu, J. Silencing CDR1as inhibits colorectal cancer progression through regulating microRNA-7. Oncotargets Ther. 2017, 10, 2045-2056. [CrossRef] [PubMed]

153. Su, C.; Han, Y.; Zhang, H.; Li, Y.; Yi, L.; Wang, X.; Zhou, S.; Yu, D.; Song, X.; Xiao, N.; et al. CiRS-7 targeting miR-7 modulates the progression of non-small cell lung cancer in a manner dependent on NF- $\mathrm{kB}$ signalling. J. Cell. Mol. Med. 2018. [CrossRef] [PubMed]

154. Pan, H.; Li, T.; Jiang, Y.; Pan, C.; Ding, Y.; Huang, Z.; Yu, H.; Kong, D. Overexpression of Circular RNA ciRS-7 Abrogates the Tumor Suppressive Effect of miR-7 on Gastric Cancer via PTEN/PI3K/AKT Signaling Pathway. J. Cell. Biochem. 2018, 119, 440-446. [CrossRef] [PubMed]

155. Bernassola, F.; Karin, M.; Ciechanover, A.; Melino, G. The HECT family of E3 ubiquitin ligases: Multiple players in cancer development. Cancer Cell 2008, 14, 10-21. [CrossRef] [PubMed]

156. Li, F.; Zhang, L.; Li, W.; Deng, J.; Zheng, J.; An, M.; Lu, J.; Zhou, Y. Circular RNA ITCH has inhibitory effect on ESCC by suppressing the Wnt/beta-catenin pathway. Oncotarget 2015, 6, 6001-6013. [PubMed]

157. Wan, L.; Zhang, L.; Fan, K.; Cheng, Z.X.; Sun, Q.C.; Wang, J.J. Circular RNA-ITCH Suppresses Lung Cancer Proliferation via Inhibiting the Wnt/beta-Catenin Pathway. Biomed. Res. Int. 2016, 2016, 1579490. [CrossRef] [PubMed]

158. Yang, C.; Yuan, W.; Yang, X.; Li, P.; Wang, J.; Han, J.; Tao, J.; Li, P.; Yang, H.; Lv, Q.; et al. Circular RNA circ-ITCH inhibits bladder cancer progression by sponging miR-17/miR-224 and regulating p21, PTEN expression. Mol. Cancer 2018, 17, 19. [CrossRef] [PubMed]

159. Zeng, K.; Chen, X.; Xu, M.; Liu, X.; Hu, X.; Xu, T.; Sun, H.; Pan, Y.; He, B.; Wang, S. CircHIPK3 promotes colorectal cancer growth and metastasis by sponging miR-7. Cell Death Dis. 2018, 9, 417. [CrossRef] [PubMed]

160. Panda, A.C.; Grammatikakis, I.; Kim, K.M.; De, S.; Martindale, J.L.; Munk, R.; Yang, X.; Abdelmohsen, K.; Gorospe, M. Identification of senescence-associated circular RNAs (SAC-RNAs) reveals senescence suppressor CircPVT1. Nucleic Acids Res. 2017, 45, 4021-4035. [CrossRef] [PubMed]

161. Verduci, L.; Ferraiuolo, M.; Sacconi, A.; Ganci, F.; Vitale, J.; Colombo, T.; Paci, P.; Strano, S.; Macino, G.; Rajewsky, N.; et al. The oncogenic role of circPVT1 in head and neck squamous cell carcinoma is mediated through the mutant p53/YAP/TEAD transcription-competent complex. Genome Biol. 2017, 18, 237. [CrossRef] [PubMed]

162. Zhong, Z.; Huang, M.; Lv, M.; He, Y.; Duan, C.; Zhang, L.; Chen, J. Circular RNA MYLK as a competing endogenous RNA promotes bladder cancer progression through modulating VEGFA/VEGFR2 signaling pathway. Cancer Lett. 2017, 403, 305-317. [CrossRef] [PubMed]

163. Han, D.; Li, J.; Wang, H.; Su, X.; Hou, J.; Gu, Y.; Qian, C.; Lin, Y.; Liu, X.; Huang, M.; et al. Circular RNA circMTO1 acts as the sponge of microRNA-9 to suppress hepatocellular carcinoma progression. Hepatology 2017, 66, 1151-1164. [CrossRef] [PubMed] 
164. Hsiao, K.Y.; Lin, Y.C.; Gupta, S.K.; Chang, N.; Yen, L.; Sun, H.S.; Tsai, S.J. Noncoding Effects of Circular RNA CCDC66 Promote Colon Cancer Growth and Metastasis. Cancer Res. 2017, 77, 2339-2350. [CrossRef] [PubMed]

165. Leung, A.K.L. The Whereabouts of microRNA Actions: Cytoplasm and Beyond. Trends Cell Biol. 2015, 25, 601-610. [CrossRef] [PubMed]

166. Derrien, T.; Johnson, R.; Bussotti, G.; Tanzer, A.; Djebali, S.; Tilgner, H.; Guernec, G.; Martin, D.; Merkel, A.; Knowles, D.G.; et al. The GENCODE v7 catalog of human long noncoding RNAs: Analysis of their gene structure, evolution, and expression. Genome Res. 2012, 22, 1775-1789. [CrossRef] [PubMed]

167. Yang, F.; Yi, F.; Han, X.; Du, Q.; Liang, Z. MALAT-1 interacts with hnRNP C in cell cycle regulation. FEBS Lett. 2013, 587, 3175-3181. [CrossRef] [PubMed]

168. Nishizawa, Y.; Konno, M.; Asai, A.; Koseki, J.; Kawamoto, K.; Miyoshi, N.; Takahashi, H.; Nishida, N.; Haraguchi, N.; Sakai, D.; et al. Hypoxia stimulates the cytoplasmic localization of oncogenic long noncoding RNA LINC00152 in colorectal cancer. Int. J. Oncol. 2018, 52, 453-460. [CrossRef] [PubMed]

169. Kino, T.; Hurt, D.E.; Ichijo, T.; Nader, N.; Chrousos, G.P. Noncoding RNA gas5 is a growth arrest- and starvation-associated repressor of the glucocorticoid receptor. Sci. Signal. 2010, 3. [CrossRef] [PubMed]

170. Liu, H.; Lei, C.; He, Q.; Pan, Z.; Xiao, D.; Tao, Y. Nuclear functions of mammalian MicroRNAs in gene regulation, immunity and cancer. Mol. Cancer 2018, 17, 64. [CrossRef] [PubMed]

171. Portnoy, V.; Lin, S.H.; Li, K.H.; Burlingame, A.; Hu, Z.H.; Li, H.; Li, L.C. saRNA-guided Ago2 targets the RITA complex to promoters to stimulate transcription. Cell Res. 2016, 26, 320-335. [CrossRef] [PubMed]

172. Schwartz, J.C.; Younger, S.T.; Nguyen, N.B.; Hardy, D.B.; Monia, B.P.; Corey, D.R.; Janowski, B.A. Antisense transcripts are targets for activating small RNAs. Nat. Struct. Mol. Biol. 2008, 15, 842-848. [CrossRef] [PubMed]

173. Leucci, E.; Patella, F.; Waage, J.; Holmstrom, K.; Lindow, M.; Porse, B.; Kauppinen, S.; Lund, A.H. microRNA-9 targets the long non-coding RNA MALAT1 for degradation in the nucleus. Sci. Rep. 2013, 3, 2535. [CrossRef] [PubMed]

174. Li, C.Y.; Liang, G.Y.; Yao, W.Z.; Sui, J.; Shen, X.; Zhang, Y.Q.; Peng, H.; Hong, W.W.; Ye, Y.C.; Zhang, Z.Y.; et al. Integrated analysis of long non-coding RNA competing interactions reveals the potential role in progression of human gastric cancer. Int. J. Oncol. 2016, 48, 1965-1976. [CrossRef] [PubMed]

175. Zhao, L.; Liu, B. Identification of potential prognostic ceRNA module biomarkers in patients with pancreatic adenocarcinoma. Oncotarget 2017, 8, 94493-94504. [CrossRef] [PubMed]

176. Yao, K.; Wang, Q.; Jia, J.; Zhao, H. A competing endogenous RNA network identifies novel mRNA, miRNA and lncRNA markers for the prognosis of diabetic pancreatic cancer. Tumour Biol. 2017, 39. [CrossRef] [PubMed]

177. Li, F.; Huang, C.; Li, Q.; Wu, X. Construction and Comprehensive Analysis for Dysregulated Long Non-Coding RNA (lncRNA)-Associated Competing Endogenous RNA (ceRNA) Network in Gastric Cancer. Med. Sci. Monit. 2018, 24, 37-49. [CrossRef] [PubMed]

178. Wu, C.; Wei, Y.; Zhu, Y.; Li, K.; Zhu, Y.; Zhao, Y.; Chang, Z.; Xu, Y. Identification of cancer-related potential biomarkers based on lncRNA-pseudogene-mRNA competitive networks. FEBS Lett. 2018, 592, 973-986. [CrossRef] [PubMed]

179. Zhang, Y.; Li, X.; Zhou, D.; Zhi, H.; Wang, P.; Gao, Y.; Guo, M.; Yue, M.; Wang, Y.; Shen, W.; et al. Inferences of individual drug responses across diverse cancer types using a novel competing endogenous RNA network. Mol. Oncol. 2018. [CrossRef] [PubMed]

180. O'Connell, M.R.; Oakes, B.L.; Sternberg, S.H.; East-Seletsky, A.; Kaplan, M.; Doudna, J.A. Programmable RNA recognition and cleavage by CRISPR/Cas9. Nature 2014, 516, 263-266. [CrossRef] [PubMed]

181. Nelles, D.A.; Fang, M.Y.; O'Connell, M.R.; Xu, J.L.; Markmiller, S.J.; Doudna, J.A.; Yeo, G.W. Programmable RNA Tracking in Live Cells with CRISPR/Cas9. Cell 2016, 165, 488-496. [CrossRef] [PubMed]

182. Abudayyeh, O.O.; Gootenberg, J.S.; Essletzbichler, P.; Han, S.; Joung, J.; Belanto, J.J.; Verdine, V.; Cox, D.B.T.; Kellner, M.J.; Regev, A.; et al. RNA targeting with CRISPR-Cas13. Nature 2017, 550, 280-284. [CrossRef] [PubMed]

183. Cox, D.B.T.; Gootenberg, J.S.; Abudayyeh, O.O.; Franklin, B.; Kellner, M.J.; Joung, J.; Zhang, F. RNA editing with CRISPR-Cas13. Science 2017, 358, 1019-1027. [CrossRef] [PubMed]

(C) 2018 by the authors. Licensee MDPI, Basel, Switzerland. This article is an open access article distributed under the terms and conditions of the Creative Commons Attribution (CC BY) license (http:/ / creativecommons.org/licenses/by/4.0/). 